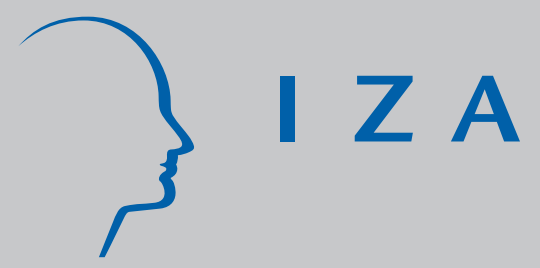

IZA DP No. 1307

Regional Income Inequality in Selected Large Countries

Almas Heshmati

September 2004 


\title{
Regional Income Inequality in Selected Large Countries
}

\author{
Almas Heshmati \\ Seoul National University \\ and IZA Bonn
}

\section{Discussion Paper No. 1307 \\ September 2004}

IZA

P.O. Box 7240

53072 Bonn

Germany

Phone: +49-228-3894-0

Fax: +49-228-3894-180

Email: iza@iza.org

Any opinions expressed here are those of the author(s) and not those of the institute. Research disseminated by IZA may include views on policy, but the institute itself takes no institutional policy positions.

The Institute for the Study of Labor (IZA) in Bonn is a local and virtual international research center and a place of communication between science, politics and business. IZA is an independent nonprofit company supported by Deutsche Post World Net. The center is associated with the University of Bonn and offers a stimulating research environment through its research networks, research support, and visitors and doctoral programs. IZA engages in (i) original and internationally competitive research in all fields of labor economics, (ii) development of policy concepts, and (iii) dissemination of research results and concepts to the interested public.

IZA Discussion Papers often represent preliminary work and are circulated to encourage discussion. Citation of such a paper should account for its provisional character. A revised version may be available directly from the author. 


\begin{abstract}

\section{Regional Income Inequality in Selected Large Countries*}

Income inequality can be measured at different levels of aggregation such as global, continental, international and national levels. Here we consider income inequality at the national level but the focus is on the within country regional inequality. Regional inequality in income distribution in a selection of large countries measured by the size of their population and land area with regional, provincial or federation division is examined. The empirical results reported are based on the second half of the 20th century. The countries considered here cover large transition, developing and industrialised countries. The review cover a whole range of measures and methods frequently employed in empirical analysis of income inequality and income distribution. Different determinant factors and their impacts from different studies are presented. Empirical results from the literature is compared with those obtained based on the WIID data covering post 1950.
\end{abstract}

JEL Classification: $\quad$ C10, D31, D63, I30, N30

Keywords: income inequality, income distribution, regions, provinces, federations

\author{
Almas Heshmati \\ Techno-Economic \& Policy Program \\ College of Engineering \\ Seoul National University \\ Bldg \# 38, Room 410 \\ San 56-1, Shilim-dong, Kwanak-gu \\ Seoul 151-742 \\ Korea \\ Email: heshmati@snu.ac.kr
}

\footnotetext{
* An earlier version of this paper was completed while I was working at the World Institute for Development Economic Research, UNU/WIDER. Comments and suggestions from Amit Kumar Bhandari is gratefully acknowledged.
} 


\section{INTRODUCTION}

The increased interest in the level, causes and development of global income inequality has been considerable in the 1990s. This has resulted in an extensive literature emerging in recent years that has focused on measurement, decomposition and on the study of how the distribution of incomes across countries that has globally developed over time. In several cases the empirical results suggest the tendency for income per capita to converge, and also an increase in inequality in the distribution of personal income in many countries. The increased interest in income inequality is due to cause and effect of the availability of income distribution data and increased awareness about income inequality, poverty and their linkage to non-income inequalities. Availability of household surveys covering many developing countries has been improved and a number of standardised databases have been created. This allows analysis of income distribution at the most disaggregate individual or per capita household levels, as well as at intermediate aggregation level such as at sub-groups or regional levels.

Income distribution is often analysed at three levels of aggregation, namely global, international and intra-national (see Heshmati 2004a). Global or world income inequality refers to inequality differences between all individuals in the world (Milanovic 2002; Schultz 1998; Quah 1999; Bourguignon and Morrisson 2002; Sala-iMartin 2002), while international income inequality refers to the economic disparity between countries (Acemoglu 2002; Cornia and Kiiski 2001; Gothscalk and Smeeding 1997; Milanovic 2001). At the intra-national level inequality refers to the distribution of income among people within individual countries (Cameron 2000; Cowell, Ferreira and Lichtfield 1998; Gustafsson and Shi 2002; Liebbrandt, Woolard and Woolard 2000). Income inequality, in addition to the extreme level of global and international, it can be measured at continental and sub-continental level consisting of geographic or economic regions (for a recent survey see Heshmati 2004b). There are evidences that poverty and inequality has developed differently among transition economies (Milanovic and Ytzhaki 2001; Ivaschenko 2002; Ram 1995; Wan 2002b), East Asian countries (Kakwani and Krogkaew 2000; You 1998) the European Union (Ritakallio 2001; Belbo and Knaus 2001; Gothschalk and Smeeding 2000; Iacoviello 1998; Lindert and Williamson 2001; Mahler 2001), Latin American (LondoNo and Szekely 2000; Wood 1997) and sub-Saharan African (Milanovic and Yitzhaki 2001; Canagarajah, Newman and Bhattamishra 2001; Svedborg 2002) countries.

A discussion of the benefit and limitations of each approach in the measurement of world income inequality is important for number of reasons, including the increased awareness of the problem, its measurement and quantification, identification of causal factors and for policy measures to affect inequality. Many of these studies show that inequality and poverty are related to a number of determinant factors. Due to the availability of data, the empirical results are mainly based on the second half of the twentieth century. Here our aim is to cover a range of measures and methods which frequently employed in empirical analysis of global and regional income inequality and income distribution. Different determinant factors, quantification of their impacts and empirical results from different case studies are discussed. These results are further contrasted to those obtained for the World Income Inequality Database (WIID) which embodies almost the same period and the group of countries. 
In addition to the levels listed above the income inequality can be measured at a withincountry regional level. Here the focus is on inequality in income distribution in a selection of large countries measured in terms of the population size and land area, where regions include states, provinces, federations or distinct geographic locations within a country. Such studies focus on large countries like China (Tsui 1993; Xu and Zou 2000; Lee 2000; Gustafsson and Shi 2002), Russia (Commander, Tolstopiatenko and Yemtsov 1999; Yemtsov 2002; Luttmer 2001; Shorrocks and Kolenikov 2001; Fedorov 2002), India (Mishra and Parikh 1997; Jha 2000; Datt and Ravallion 1992) and the USA (Patridge, Rickman and Levernier 1996; Black and Dowd 1997; Zandvakili 1999; Moffitt and Gothschalk 2002), as well as a number of smaller developing and transition countries with major impacts on global inequality and poverty.

China and India experienced rapid economic growth after economic reform, accompanied by increased inequality and the reduction in poverty. The level and development of inequality has varied by location and sector. This inequality can further be decomposed into various components associated with inter- and intra-sector and provincial components and their determinants in turn identified (see Heshmati 2004c). Analysis of within-country regional inequality can reveal effects of openness, marketisation, convergence due to factor mobility, and may also indicate regional polarisation, or disintegration and widening inequality driven by structural differences between regions. Furthermore it is important to consider heterogeneity in income inequality in both level and development over time, as well as different characteristics of sub-group dimensions. Empirical evidence suggests that inequality and poverty alter following structural adjustment programmes affecting the welfare of sub-groups of a population differently.

In this paper we review income inequality within country but at the regional level. Regional inequality in income distribution in a selection of large countries with regional division is examined. In some cases region is equivalent of states like in India and USA, provinces in China, or members of a Federation in Russia. In certain cases it can also be defined as more aggregated geographical coastal, central and western regions in China or geographic regions in Russia. The empirical results reported here are based on the second half of the $20^{\text {th }}$ century. The countries considered here cover transition (China and Russia), developing (India) and industrialised (USA) countries. Empirical results from the literature is further complemented and compared with those obtained from the WIID data covering post 1950 s.

Rest of the paper is organised as follows. The next section is inequality in China. Here we discuss the issues of provincial, regional and sectoral income inequality and its decomposition, policy measure to reduce inequality as well as convergence and polarisation. In section 3 we investigate inequality in Russia. We discuss inequality and transition, inequality and regional polarisation, wage inequality, and inequality decomposition. Regional inequality in India is discussed in Section 3. The focus is on state and sectoral inequality and polarisation. Great emphasis is put on the inequalitypoverty-growth relationship. Section 4 is on regional inequality in USA. The focus is on South, Non-South, and interstate income inequality and factors affecting inequality. Inequality in a selection of smaller countries is discussed in Section 5. The WIID data is described in Section 6. Results based on WIID are presented in Section 7. The final Section summarises. 


\section{REGIONAL GROWTH, INEQUALITY AND POLARIZATION IN CHINA}

Empirical studies of inequality and poverty in China is often based on two surveys conducted by the Institute of Economics, Chinese Academy of Social Sciences, with the assistance of the State Statistical Bureau (SSB) in Beijing. The first survey of household income for 1988 was implemented in 1989 and the second for 1995 in 1996. Sample households are visited every month by an enumerator for 5 years. The sample size in the first survey was about 20000 households and about 15000 in the second. The rural sample cover 109 counties located in 19 provinces and the urban sample cover cities located in 11 provinces. The provinces are chosen such as to reflect the geographical differences in China. The data allow studies of inequality and poverty by sub-groups, income sources, various household characteristics, sectors and locations. For a short description of the data see Gustafsson and Zhong (2000) and Gustafsson and Shi (2001a).

\section{Provincial inequality and growth}

China has experienced rapid economic growth with major impact on inequality during recent decade. Xu and Zou (2000) using a new panel data set about Chinese provincial urban level income inequality show that the Gini coefficient increased from 0.17 in 1985 to 0.23 in 1995. The period average varies in the interval 0.17 and 0.25 by provinces and 0.13 and 0.34 by year observation. The data is obtained from urban household surveys in each of the 29 provinces and various provincial statistical yearbooks covering the period of 1985-1995 (except 1987 and 1988). Based on average incomes for each 5 percentiles, $\mathrm{Xu}$ and Zou compute the Gini coefficients, percentage of income of bottom, top and the third and fourth quintiles and the ratio of top to bottom quintiles for each province.

Since the beginning of the economic reforms initiated in 1978, Xu and Zou find that aggregate output growth has been on the average 9.9 per cent per year while the average growth in GDP per capita was 8.8 per cent during the period of 1978-1994. The difference must be explained by changes in the population. The growth rates differ by the location between 4.8 per cent for inland and 14.2 per cent for coastal provinces. The correlation between the growth rate and Gini coefficient is 0.27 and seem to support the Kuznet's (1955) inverted U-curve. This contradict the Alesina and Rodrik (1994) and Person and Tabellini (1994) findings based on cross-section of international data who observed a negative association between income growth and inequality. In analysing the causal mechanism relating inequality and growth in India and China, Quah (2002) pointed out that there is no single evidence about such relation. Many other factors like macroeconomic, technological, political or institutional beyond inequality influence economic growth. Ravallion (1998) suggests that aggregation can bias tests of whether inequality impedes growth. Empirically the effects of asset inequality on consumption growth for rural household in China evaluated. The effect is lost in regional growth models.

\section{Determinants of provincial inequality}

In above we reviewed research identifying factors beyond inequality that influence economic growth. Xu and Zou (2000) looks at the reverse link, i.e. the role played by output growth, increasing exposure to international trade, urbanisation, taxation, government spending, inflation, human capital formation, geography, and the sectoral 
structure of the economy in determining the changes in income inequality. The relation is specified as:

$$
\begin{gathered}
I N E Q_{i t}=\beta_{0}+\beta_{S O E} S O E_{i t}+\beta_{I N F} I N F_{i t}+\beta_{D I S} D I S_{i t}+\beta_{S C H} S C H_{i t}+\beta_{G D P} G D P_{i t} \\
+\beta_{T R A} T R A_{i t}+\beta_{E X P} E X P_{i t}+\beta_{U R B} U R B_{i t}+\phi_{i}+\varepsilon_{i t}
\end{gathered}
$$

where $I N E Q_{i t}$ is Gini coefficient or it can alternatively be measured as the (ratios of) quintile income shares Q5/Q1, Q5, Q1, or Q34. The $\phi_{i}$ captures unobserved provincespecific effects. The explanatory variables are: the share of state-owned enterprises $(S O E)$, the inflation rate $(I N F)$, distance of a province's capital to the nearest port by railroad $(D I S)$, the share of residents with more than secondary schooling (SCH), GDP growth rate $(G D P)$, trade measured as the ratio of value of import and export to GDP $(T R A)$, the share of government expenditure as a share of GDP $(E X P)$, and the change of urbanisation level of a province measured as the growth rate of the share of nonagricultural population in the province $(U R B)$. The results show that income distribution has been affected by the changing structure of the economy, the role of the state, and increasing urbanisation. Inequality and Q5 increased (and Q1 decreased) with reduction of SOE share of output, higher inflation, higher growth rate, and foreign trade. Government spending tends to shift resources from the rich and the poor to the middle class. Provinces farther from coast had larger inequality probably reflecting greater imperfection of capital market. Schooling and increasing urbanisation did not affect income inequality. It has not been possible to identify determinants of (unobserved) level differences in inequality across different provinces.

\section{Regional and sectoral inequality decomposition}

Since the impacts of economic reform are regionally dissimilar in China, not only interprevincial but also intraprovincial, intra-rural, intra-urban, and rural-urban inequality are crucial in analysing China's regional inequality. Tsui (1993) decompose China's regional inequality into the five components mentioned above using per capita gross value of industrial and agricultural outputs for 1982. The decomposition is based a simple principle where the overall inequality $(I)$ of each attribute is the sum of withingroup $(W G)$ and between-group $(B G)$ inequalities expressed as:

$$
I\left(X_{i}\right)=W G_{i}+B G_{i}
$$

where the terms within-group and between-groups are then equivalent to intraprovincial and interprovincial inequalities. The results show that both intraprovincial and interprovincial inequality is the important sources of China's regional inequality. Disparity among the coastal, central and western regions is insignificant but the variance within the coast is substantial. Inter-rural and inter-urban inequality accounts for a large share of intraprovincial and overall inequality but neither of intra-rural and intra-urban are crucial factors to the development of inequality. Eastwood and Lipton (2000) discuss the changes in the focus of reforms in China post 1983. The focus shifted from rural agricultural liberalisation to the urban sector industrial liberalisation with wages more tied to labour productivity. During 1983-1995 substantial rises in total, intra- and intersectoral inequalities have been observed. However, inequality was rising faster in the urban sector. Unlike expectations adjustments and liberalisations have not resulted in narrowing the urban-rural gap. Gustafsson et al. (2001) find strong 
relationship between age and wage indicating that seniority play a strong role in determining earnings in urban China.

Lee (2000) reinvestigates the Tsui's (1993) findings using recent and more disaggregate data from China's 2165 cities and counties in 1994 but applying the same decomposition method. Per capita consumption ${ }^{1}$ and gross value of industrial and agricultural outputs are used as a measure of income. For the decomposition of the inequality index, Theil's entropy measured is defined as:

$$
I(y)=\sum_{i=1}^{n} f_{i} \log \left(\frac{\mu}{y_{i}}\right)=\sum_{g=1}^{G} w_{g} I\left(y_{g}\right)+i\left(\mu_{1} e_{1}, \mu_{2} e_{2}, \ldots, \mu_{G} e_{G}\right)
$$

where $y$ is per capita consumption, $\mu_{g}$ is the population weighted mean of observation for subgroup $g, G$ is the number of subgroups, $f_{i}=P_{i} / P$ is the $i$ th county's population share, $w_{g}=\left(n_{g} / n\right)$ is population weight, and $e_{g}$ is an $n_{g}$ vector of ones capturing unobserved subgroup effects. The weighted sum, $I\left(y_{1}\right), I\left(y_{2}\right), I\left(y_{3}\right)$, are the inequality within coastal, central and western regions, $w_{1} I\left(y_{1}\right), w_{2} I\left(y_{2}\right), w_{3} I\left(y_{3}\right)$ is intra-regional inequality, while $I\left(\mu_{1} e_{1}, \mu_{2} e_{2}, \mu_{3} e_{3}\right)$ is the inter-regional inequality and $\left(w_{1} I\left(y_{1}\right) / I(y)\right) \times 100$ or $\left.\left(\mu_{1} e_{1}\right) / I(y)\right) \times 100$ are percentage contribution of coastal region intra-regional and inter-regional inequality to the overall inequality.

The results in Lee show that: rural-urban disparity has been reduced in turn reducing the intraprovincial inequality. The dominant sources of overall inequality in output have shifted from the intraprovincial to interprovincial inequality, from rural-urban to intrarural inequality, from disparity within the coastal region to the gap between coastal and interior regions. Disparity among coastal, central and western regions has increased while the gap between rural and urban within each region has narrowed. Disparity among the three regions is a dominant source of regional inequality. Output and consumption measures produce different inequality levels and rankings, 0.39 and 0.33 . The share of intra(inter)provincial inequality of the overall inequality is 48.5 (51.5 per cent) for output and 63.2 (36.8 per cent) for consumption measures. In the case of consumption, the intraprovincial inequality, rural-urban inequality, and disparity within the coastal region are crucial factors of the overall regional inequality. The role of intraurban income inequality is currently significant. The coastal and rural-industry-led growth aggravates the intra-rural output inequality. Kanbur and Zhang (1999) also conclude that the contribution of rural-urban disparities to regional inequality far exceeds the contribution of increasing inland-coastal disparities. Difference in the ease of migration provides a partial explanation for the phenomenon.

Gustafsson and Shi (2002) investigated how income inequality varies within and across counties in rural China. Household data covering 18 provinces in 1988 and 1995 is used. Results show that income inequality in rural China has increased rapidly. Differences in mean income between counties within provinces, between provinces as well as diverging means by regions are major contributors to rural inequality. Part of the income inequality within Chinas provinces is spatial. However, Ravallion and Chen (1999) argued that the structural changes in the rural economy are not reflected in the

\footnotetext{
${ }^{1}$ Tsui (1993) used per capita gross value of industrial and agricultural outputs as measures of income.
} 
methods used for processing the raw data. Two third of the increase in inequality vanishes when market-based valuation methods are used and allowances are made for regional cost-of-living differences. Using the same data as in Gustafsson and Shi (2002) Gustafsson and Zhong (2000) found that despite impressive economic growth poverty has decreased only slightly due to the changed demographic composition of the population. Based on a common poverty line the poverty is characterised to be a rural and also a geographical problem. The effectiveness of regional targeting in China's poverty alleviation program for 2 the period 1981-1995 is evaluated by Park, Wand and $\mathrm{Wu}$ (2002). They find modest positive effects on rural income growth. Perfect targeting may not be optimal due to tradeoffs between targeting and other social objectives.

Income source is important to inequality. In a regression-based approach Morduch and Sicular (2002) examined inequality decomposition by income source. The method is illustrated based on a small farm level data from rural China and compared to Theil-T, $\mathrm{CV}$ and Gini decomposition methods. The role of regional segmentation, education, age and political variables is emphasised. The results are found to be sensitive to the choice of decomposition method. Wan (2001) also decomposed changes in regional income inequality in rural China into structural, real inequality and interactive effects by decomposing Gini index by income (wage, farming and residual) sources. Structural effects found to be the driving force underlying increased regional inequality in rural China. The pitfalls in regression-based inequality decomposition are discussed by Wan (2002a). A simple procedure is suggested to rectify these pitfalls. Based on results from data on 30 Chinese regions during 1992-1995 Wan argues that the root of problems relating to constant and residuals are not caused by inequality, rather than lie in the construction of proposed decomposition methodologies.

\section{Convergence in per capita income}

China's experience with trade liberalisation after 1978 and with rapid growth in the coastal provinces, give indication of widening inequality among China's diverse regions. Jian, Sachs and Warner (1996) examine the tendency towards convergence in real per-capita income among the provinces of China during the period 1952-1993. No strong convergence or divergence during the initial phase of central planning (19521965) was observed. There is strong evidence of divergence during the cultural revolution (1965-1978) with social planning in favour of richer industrial regions widened the inter-regional inequality. Regional inequality equalised with the extent of marketization and openness that begun in 1978. Convergence is due to factor mobility, flow of labour, capital and technology, increased productivity among the rural regions and convergence within the coastal provinces. A policy to further liberalisation of interior will also promote convergence. Variance decomposition of the log of real DGP $\left(x_{i}\right)$ in each province $i$ is obtained using the formula:

$$
\operatorname{Var}(x)=a_{1} \operatorname{Var}\left(x_{1 i}\right)+a_{2} \operatorname{Var}\left(x_{2 i}\right)+a_{12}\left(\bar{x}_{1}-\bar{x}_{2}\right)^{2}
$$

where 1 and 2 refers to the coastal and interior regions, $a_{1}$ and $a_{2}$ are weights that depend on the number of provinces in each of the two regions, and $\bar{x}_{1}$ and $\bar{x}_{2}$ denote means of $\log$ of real GDP by region. Zhang, Liu and Yao (2001) investigate the timeseries properties of per capita income in China's regions during 1952 to 1997 and compare the consistency of results with cross-sectional methods. The innovation outlier model of the log of relative per capita income $(R I)$ of Perron (1989) is estimated as: 


$$
\Delta R I_{t}=\beta_{0}+\beta_{t} t+\beta_{D T} D\left(T_{B}\right)_{t}+\beta_{D U} D U_{t}+\beta_{D T} D T_{t}+\beta_{R I} R I_{t-1}+\sum_{k=1}^{K} \beta_{k} \Delta R I_{t-k}+\varepsilon_{t}
$$

where $T_{B}$ is the break year, $K$ is maximum of lag length, $D\left(T_{B}\right)_{t}=1$ if $t=T_{B}+1$, otherwise $0, D U_{t}=1$ if $t>T_{B}$, otherwise 0 , and $D T_{t}=t-T_{B}$ if $t>T_{B}$, otherwise 0 . The specification allows to test changes in intercept $\left(\beta_{D U}=0\right)$ and/or slope $\left(\beta_{D T}=0\right)$. The results based on Gini coefficient, the ratio of per capita income between regions and the coefficient of variation suggests that eastern and western regions have converged to their own specific steady states over the past 40 years. The regional gap between the east and other regions widened before the reforms but economic reforms has worsened the gap further.

\section{Policy measure to reduce inequality}

Khan and Riskin (2001) provide a comprehensive analysis of inequality and poverty in China in the age of globalisation. Based on the 1988 and 1995 survey data they observe major changes in the composition of income between the two survey dates. Rural household income mainly from farming has declined from 74 per cent to 56 per cent, while non-farming wages increased from 9 per cent to 22 per cent resulting in increasing income inequality. The Gini ratio for rural income grew by 23 per cent from 0.34 to 0.42 due to unequal distribution of faster-growing wage components of rural income. The corresponding increases in inequality in the urban areas 43 per cent in seven years from 0.23 to 0.33 . The increasing inequality of distribution of income caused rise in urban income inequality. The wage share of income grew from 44 per cent to 61 per cent. Other components of income like income of retirees and housing rental were subject to fast growth as well. Subsidies declined from 20 per cent of urban income to 1 per cent.

Demurger et al. (2002) examined the growth in GDP per capita for the period 19521998 and decomposed the location and policy growth rates in the provincial growth regressions to quantify the contribution of each factor in 1996-1999. Their respective contribution varies with the interval of $0-2.8$ and 1.6-3.5 per cent. The highest and lowest rates are associated with the coastal and northwestern provinces, respectively. The authors list a number of policy measures to solve the unbalanced growth and to reduce the regional disparity. The policy measures include: extension of the deregulation from coastal to include other provinces, introduction of a registration system to prevent movements from the rural poor to prosperous areas, changes in the policy of the monopoly state bank system to allocate more resources to the western provinces, improvement in the infrastructure to overcome geographical barriers, and to increase the human capital formation. Shi (2001) estimated that the growing inequality of income distribution in both rural and urban areas has created more difficulties in reducing poverty since the mid-1980s.

\section{Income factor decomposition of inequality}

Previous studies have suggested that non-agricultural activities have been the major cause of rural income inequality. Increase in agricultural income was considered as a policy measure to reduce rural inequality in China. Cheng (1996) used household data from 5 grain producing Chinese regions in 1994 and Lerman and Yitzhaki (1985) 
decomposition approach showed that Gini coefficient of total income can be expressed as:

$$
G=\sum_{k=1}^{K} R_{k} G_{k} S_{k}
$$

The above expression shows that inequality within the grain producing areas was also very high, with differences in crop income as the major source of inequality. A decomposition of inequality indicates that 61 per cent of the income inequality of peasant households is due to intraprovincial while remaining 39 per cent from the interprovincial inequality components. The $R_{k}, G_{k}$ and $S_{k}$ are Gini correlation between the income component $k$ and the rank of total income, the Gini coefficient for income component $k$, and the share of $k$ in the total income consisting of $K$ components. The inequality contribution of component $k\left(C_{k}\right)$ and marginal effect $\left(M_{k}\right)$ of a percentage change in income source $\mathrm{k}\left(e_{k}\right)$ are obtained from:

$$
C_{k}=R_{k} G_{k} S_{k} / G \quad \text { and } \quad M_{k}=\frac{\partial G / \partial e_{k}}{G} .
$$

We have already described an example of decomposition of Gini by income source. In the second study which based on different approach of the Gini coefficient of household income according to type of income. This has decomposed by Gustafsson and Shi (2001b) to analyse the reasons for the rapid increase of income inequality. They investigateed the effect of the processes of economic and social transition on the distribution of income in China. The Gini coefficient and the differences of the Gini coefficient between two years, 1 and 0 , is written as:

$$
\begin{aligned}
& G=\sum_{k=1}^{K} \frac{\mu_{k}}{\mu} C_{k} \\
& \Delta G=G_{1}-G_{0}=\sum_{k=1}^{K}\left(S_{1 k} C_{1 k}-S_{0 k} C_{0 k}\right)
\end{aligned}
$$

where $S_{k}$ is the share of income type k, $C_{k}$ is the concentration coefficient of income type $k$ measuring the association between income type $\mathrm{k}$ and total income, and $\mu_{k}$ and $\mu$ are means of income type $k$ and total income respectively. Results based on samples of 1988 and 1995 household surveys shows that the changes in relative size of money income due to the distribution of land by household size and its changed profile are found to be the major processes behind the rapid increase of income inequality in rural China. Changes in the urban housing allocation and an increased number of retirees in combination with higher benefits have made inequality to increase. Using the same data Gustafsson and Shi (2001a) in analysing the Chines labour market to investigate how earnings ${ }^{2}$ inequality and relative earnings have changed between 1988 and 1995. The mean logarithmic deviation $(M L D)$ index and the changes in the $M L D$ between two periods are written as:

\footnotetext{
${ }^{2}$ Total earning is decomposed into basic wages, bonus, subsidies and other earnings.
} 


$$
\begin{aligned}
L & =\sum_{k=1}^{K} \log \left(\frac{\mu}{y_{k}}\right) / N \\
\Delta L & =L_{t+\tau}-L_{t} \approx A+B+C+D \\
& \approx \sum_{k=1}^{K} \bar{v}_{k} \Delta L_{k}+\sum_{k=1}^{K} \bar{L}_{k} \Delta v_{k}+\sum_{k=1}^{K}\left(\bar{\lambda}_{k}-\ln \bar{\lambda}_{k}\right) \Delta v_{k}+\sum_{k=1}^{K}\left(\bar{\theta}_{k}-\bar{v}_{k}\right) \Delta \ln \mu_{k}
\end{aligned}
$$

where $\Delta$ represents changes, $\mu_{k}$ is the mean value, $v_{k}$ is the share of group observations in total, $\lambda_{k}=\left(\mu_{k} / \mu\right), \theta_{k}=\left(v_{k} \lambda_{k}\right)$ and $\tau$ is incremental time period. The total change is decomposed into 4 components. These are interpreted as: the effect of intertemporal changes in inequality within groups $(A)$, the effect of changes in population shares on the within-group inequality $(B)$, the effect of changes in population shares on the relative mean earnings of the population group $(C)$, and the relative mean earnings of the population groups $(D)$. The overall effects of demographic changes is equal to the sum of $B$ and $C$. Results show that earnings inequality has increased rapidly affecting all categories of labour as defined by ownership sector, region and education. The contribution of basic wages and subsidies to inequality increase is positive, while those of bonus and other earnings negative.

\section{Polarization vs inequality indices}

To overcome the limitation of the two inequality (Gini and Generalized Entropy) indices and three polarisation (Esteban-Ray 1994; Wolfson 1994; and Tsui-Wang 1998) indices in establishing along which dimension polarisation occurs, Kanbur and Zhang (1999) developed a polarisation index $(K Z)$ by specifying clusters and measuring the extent of inequality decomposed into within-group and between-group inequality components. Polarisation refers to clustering of the income distribution along some key dimensions. The indices of Zhang and Kanbur (2001) are written as:

$$
\begin{aligned}
& E R=A \sum_{i=1}^{K} \sum_{j=1}^{K} \pi_{i} \pi_{j} \pi_{i}^{a}\left|y_{i}-y_{j}\right| \\
& W=\frac{2(2 T-G)}{(m / \mu)}=\frac{2\left(\mu^{*}-\mu^{L}\right)}{m} \\
& T W=\frac{\theta}{N} \sum_{i=1}^{K} \pi_{i}\left|\frac{y_{i}-m}{m}\right|^{r} \\
& K Z=\frac{I^{B}(y)}{I^{W}(y)}=\frac{\sum_{k=1}^{K} w_{k} I_{k}}{I\left(\mu_{1} e_{1}, \mu_{2} e_{2}, \ldots, \mu_{K} e_{K}\right)}
\end{aligned}
$$

where $G$ is the Gini coefficient, $I$ is inequality index, the subscript $k$ indicates income group, the superscripts $B, W, a$, and $r$ denote between, within, and sensitivity parameters, $\pi_{i}$ is the population frequency in every class, $A$ is used for population normalisation, $\mu^{*}=(1-G)$ and $\mu^{L}$ is the distribution of corrected mean income and mean income of the bottom half of the population. The $K Z$ index is expressed as the ratio of between inequality and within inequality. The index is then calculated for each 
of the four dimensions: West-East, National status, Capital city size and Export share by using income and expenditure definitions. In testing the behaviour of the four indices, it is found that the polarisation indices do not produce different results from the inequality indices. The $K Z$ index seems to offer more insights into changes in China's income distribution. The results show that while polarisation along West-East and national status dimensions remained constant, polarisation along capital city size and export share dimensions increased during 1983-1995. The conclusion is that regional polarisation is driven by structural differences between regions rather than geographic or political. In terms of levels, rural-urban polarisation is more serious than inland-cost, while in terms of trend, the inland-coast polarisation has increased much more than rural-urban. Birchenall (2001) used the following modified formulation of the Esteban and Ray as a measure of polarisation:

$$
B=A \sum_{i=1}^{K} \sum_{j=1}^{K} \pi_{i}^{1+\alpha} \pi_{j}\left|y_{i}-y_{j}\right|
$$

where $A=\left[\sum_{i=1}^{K} \pi_{i}\right]^{-(2+\alpha)}$ is used for population normalisation. The measure is applied to Colombian income distribution. Human capital accumulation reduced the dispersion of income distribution leading to a period of stagnation when mobility declined. The structural reforms made the economy less equal but increased mobility.

\section{Summary of regional inequality in China}

China has experienced rapid economic growth in the post economic reform initiated in 1978 with the implications for inequality. Research analysing income inequality in China is often based on household surveys collected in late $80 \mathrm{~s}$ and $90 \mathrm{~s}$ or published statistics at regional level. The surveys are of good coverage when regional, provincial and sectoral dimensions are considered. There is a general agreement among research presented above that Gini coefficient increased over time and heterogeneously across provinces. The dissimilar impact of growth on inequality is not limited to interprovincial, but also intraprovincial, intra-urban, intra-rural and rural-urban inequality. Intraprovincial, intra-rural and intra-urban inequality components contribute significantly to the overall inequality. The growing inequality has created more difficulties in reducing poverty. Income sources are differently important to the sectoral inequality. The correlation between the growth and inequality support the Kuznet's inverted U-curve relationship. In analyzing the causal mechanism relating inequality and growth many other factors like macroeconomic, technological, political and institutional factors beyond the inequality influence of economic growth. Output growth, increasing exposure to international trade, urbanisation, taxation, government spending, inflation, human capital, geography and the sectoral structure of the economy determine the extent and direction of changes in inequality. The regional polarisation is driven by structural differences between regions.

\section{REGIONAL INEQUALITY IN RUSSIA}

The Russian Household Budget Survey (HBS) conducted since 1952 by Goskomstat and the Russian Longitudinal Monitoring Survey are the main data source used in analysis of income inequality, income distribution and poverty in Russia. The Soviet 
style family budget nature of the survey was revamped in 1997. The new sample covers around 49000 families observed on quarterly basis. It is representative of each region (89 territorial units or Federations) of Russia for urban/rural subgroups. For a brief description of the HBS data see Yemtsov (2002).

\section{Inequality and transition}

Unlike other transition economies, the level of inequality defined as Gini coefficient and Theil mean log deviation index was quite high when Russia entered transition. Using the Russian Longitudinal Monitoring Survey dataset Commander, Tolstopiatenko and Yemtsov (1999) demonstrate that inequality rose further. A number of factors are identified as the driving forces behind the increases. The factors are the wealth transfers through privatisation programme, changes in government expenditure, growth in earnings dispersion, and shifts in the structure of income. Yemtsov (2002) also analyses inequality and poverty in the Russian regions over the period 1992-2000. Yemtsov uses household budget survey (HBS) data to construct regional level data. Results show significant between and within regional inequality with increasing trend. The dynamics of poverty depend on inter-regional differences in the average incomes. The observed regional differences in inequality are related to endowments and initial conditions, transfers, restructuring policies, and economic shocks.

Regarding the incidence and the depth of poverty during 1992-1996, Commander, Tolstopiatenko and Yemtsov (1999) results indicate that at the start of transition about half of the population of households fell below the region-specific poverty lines. Poverty is measured as headcount, poverty gap and the squared poverty gap. The share declined to 40 per cent at the end of 1996, but a large fraction of households were locked in chronic poverty. Luttmer (2001) also suggests that after accounting for transitory shocks around 80 per cent of the poor in Russia and Poland remains in poverty for at least one year. Results in Shorrocks and Kolenikov (2001) covering the period 1985-1999 suggest that falling real per capita income and growing inequality each contributed to raising the poverty rate in Russia by about 20 per cent, while lowering poverty line reduced poverty by 13 per cent. Measurement errors in the data might have lead to an overestimation of the poverty rate. The data errors can be due to unregistered incomes from the growing informal economic activities and home production.

None of the factors listed above is concerned with the human capital. Human capital is found to be important for economic growth. Russia, despite its high level of human capital is having a living standard of a middle income developing country. Furthermore, Russia has experienced sharply negative growth rates for more than a decade. In finding explanations to the above patterns Fan, Overland and Spagat (1999) presented a model, using a two-sector overlapping generations framework, dealing with transition economics from a theoretical perspective placing emphasis on the importance of human capital. The model captures the characteristics of the Russian economy with both much human capital and an education system that produces the wrong skills for a market economy. The authors propose a rule for the timing of restructuring the education system and simultaneously reducing inequality. It is suggested that a late implementation of restructuring early in the transition process will reduce the Russian's investment in human capital and skills. Early education restructuring as part of the transition strategy and continuous subsidisation of the education system is 
recommended. An early restructuring is expected to reduce inequality by providing underprivileged youth with an upward mobility.

\section{Inequality and regional polarisation}

Increasing regional inequality and regional polarisation are becoming serious policy concerns of the Russian Federation. The heterogeneous economic development, size, ethnic and natural diversity of regions might cause disintegration and widening regional differences as standard of living continue to grow. Fedorov (2002) documents changes in regional inequality during 1990-1999 in per capita monetary income and expenditures and employ several measures of polarisation to analyse empirically dimensions of regional polarisation in Russia. The Generalised Entropy $(G E)$ measure and Esteban-Ray $(E R)$, Wolfson $(W)$ and Kanbur and Zhang $(K Z)$ indices of polarisation are used. The Generalised Entropy class of inequality measures in Kanbur and Zhang (1999) is written as:

$$
G E= \begin{cases}\sum_{k=1}^{K} f\left(y_{i}\right)\left(\left(y_{i} / \mu\right)^{c}-1\right), & c \neq 0,1 \\ \sum_{k=1}^{K} f\left(y_{i}\right)\left(y_{i} / \mu\right) \log \left(y_{i} / \mu\right), & c=1 \\ \sum_{k=1}^{K} f\left(y_{i}\right) \log \left(\mu / y_{i}\right), & c=0 .\end{cases}
$$

The remaining three polarisation indices are previously defined. The $K Z$ polarisation index is derived from the $G E$ index measurement. Polarisation has to do with clustering of the income distribution along key dimensions, while inequality concerns the overall distribution. The dimensions here include West vs. East, national republics vs. ethnically Russian regions, region with large capitals vs. region with smaller capitals, exporting regions vs. other regions. The household survey data used cover 77 out of a total of 89 politically equal members of the Federation which are economically distinct regions. ${ }^{3}$

Trends in regional inequality and polarisation are analysed in Fedorov (2002) by calculating Gini coefficient and the Generalised Entropy inequality measures. The Gini coefficient for income rose from 0.11 in 1991 to 0.29 in 1999 and for expenditure from 0.12 to 0.37 . Inequality is increasing before 1996 and then levels out and is constant at the end of period. The results show that the transition period affected differently not only different groups of the population but also regions. The Esteban-Ray and Wolfson indices of polarisation using Gini and income distribution parameters show that regional polarisation has been increasing since the beginning of transition with similar trends as in the inequality. ${ }^{4}$ The index is calculated for each of the four dimensions: West-East, national status, capital city size and export share by using income and expenditure definitions. The polarisation measures do not provide a better insight into the pattern of regional polarisation than Gini and Generalised Entropy measures. Polarisation is found to be increasing along the capital city size and export share dimensions while it is

\footnotetext{
${ }^{3}$ Regions with domestic conflicts are excluded from the study.

${ }^{4}$ Similarity in trends between regional inequality and the two polarization indices is found in Zhang and Kanbur (2001) for China using data from 1983 to 1995.
} 
decreasing along the West-East and national status dimensions over the course of economic transition. Based on the above observations Fedorov concludes that regional polarisation in Russia is driven by structural differences between regional rather than geographic or political.

\section{Inequality decomposition}

Yemtsov (2002) analyses inequality and poverty in the Russian regions over the period 1992-2000. Household budget survey (HBS) data is used to construct regional level data. Inequality is decomposed into inter-regional and intra-regional inequalities. The between regional inequality accounts for one third of the overall inequality and it is trended towards an internationally high level. The dynamics of poverty will increasingly depend on inter-regional differences in the average incomes. The observed differences in inequality are found to be related to a number of determinants such as endowments and initial conditions, transfers, restructuring policies, and economic shocks.

\section{Wage inequality}

Wage inequality in Russia following the end of the central planning has risen more than in Central and Eastern European (CEE) countries undergoing transition. Flemming and Micklewright (2000) investigate differences in income distribution (defined as earnings of full-time employees, per capita household incomes, and transfers) between market and planned economies. The latter are considered both during socialist and transition periods. They estimate that the Gini coefficient for per capita income in Russia rose from 0.22 before transition to 0.41 in 1994 and fell to 0.37 in 1997. Despite considerable heterogeneity, the corresponding rise in Gini for CEE was from 0.20 to 0.25 . The level was relatively high for some countries like Czech Republic, Hungary and Poland. The increase has been much higher when wage inequality in Russia is considered. Rising earnings dispersion seems to have been the major factor behind rising inequality in personal incomes. At the household level dispersion is however lower.

Due to the lack of data Flemming and Micklewright indicates that it has not been possible to account for important features of the transition like the impact of housing privatisation and the relative price effects of liberalisation on income distribution. It is worth mentioning that the comparison among countries in above is based on data that are not strictly comparable. Luttmer (2001) analysed the impact transitory shocks and measurement errors on inequality and mobility in Poland and Russia. There is a positive association between noise in the data and increased inequality. Economic insecurity is estimated to be substantial. The high levels of economic mobility, foremost in Russia, largely are driven by transitory events and noisy data.

In addition to high level of wage inequality and increasing wage dispersion unlike other CEE transition countries Russia also has an extremely large incidence of wage arrears (withholding wages) affecting the wage distribution and wage inequality. Results from Russian Longitudinal Monitoring Survey (RLMS) data for 1994, 1996 and 1998 presented by Lehman and Wadsworth (2001) shows that the conventional measure of earnings dispersion would be 20 to 30 percent lower in the absence of wage arrears. In 1998 about 70 per cent of employees did not receive a wage complete or on time. Lehman and Wadsworth discuss the pay distribution by gender, education, region and industry and quantify the wage gaps between counterfactual and observed wage 
distributions by these characteristics. ${ }^{5}$ The counterfactual group represent those not in the arrears.

\section{Summary of regional inequality in Russia}

The level of inequality in the Russia Federation has been higher than in other transition economies when Russia entered its process of transition. The factors causing the increase in inequality are wealth transfer, changes in government expenditure, growth in earnings dispersion, shifts in the structure of income and also disruption in production. Several studies point to significant between and within regional inequality with increasing trend. The regional inequality differences found to be related to endowments and initial conditions, transfers, restructuring policies and economic shocks. Measurement errors due to unregistered income, growth of the informal economic activities and home production do not allow estimation of the negative growth rate and increasing incidence of poverty with accuracy. A restructuring of the education system is suggested as an important step to avoid continuous production of wrong skills and to reduce inequality. However, increasing regional inequality, regional polarisation and heterogeneous economic development together with size, ethnic and natural diversity of regions may cause further disintegration and widening regional differences in living standards in Russia. Regional polarisation is driven by structural differences between regions rather than geographic or political. Rising income dispersion is a major factor behind rising inequality in personal income. It is to be noted that measures of inequality and poverty might be biased. The bias is a result of the fact that the effects of housing privatisation, relative price effects of liberalisation and wage arrears on income distribution are not accounted for.

\section{REGIONAL INEQUALITY IN INDIA}

Nearly all of the empirical studies of poverty, inequality, human development and labour studies in India are based on the National Sample Survey (NSS) data covering the India's 24 states in the post 1944. The NSS database includes details on consumer expenditure, demographic characteristics, and labour market statistics. The data consists of annual stratified sample household surveys collected and processed by the Indian bureau of statistics. The household sample size varies greatly between the surveys. For the short description and examples of the use of the data see Jha (2000) and Datt and Ravallion (1992).

\footnotetext{
${ }^{5}$ For extensive discussion of the issues of wage arrears in Russia see also: Earle and Sabirianova (2001) and Lehman, Wadsworth and Aquisti (1999).
} 


\section{State and sectoral inequality}

Inequality in regional economic policies is often discussed at the inter-regional level. ${ }^{6}$ But regions differ with regard to the intra-regional patterns of distributions. Mishra and Parikh (1997) focus on the measurement and use of Gini coefficient for the distribution of income per capita of household consumption expenditure in 17 major Indian states in 1983. They examined the inter-regional inequality variations. Regional inequality is decomposed into urban and rural components. They estimate the measure of inequality by approximating the observed distribution using linear interpolation and fitting a hypothetical function like log-normal distribution to calculate the inequality measure from it. Inequality can also be measured as nonparametrically without imposing any functional form of statistical distribution by specifying Lorenz curve. The parametric and non-parametric methods resulted in Gini in the range of 0.24-0.37 and 0.24-0.36, respectively. Various tests using state level regressions indicate evidence of heterogeneity among the Lorenz curves of the states. This confirms the importance of decomposition of inequality into interstate and intrastate components. The between state component contribute 50 per cent of the total inequality. The within component is large and can be further decomposed into rural and urban components. The rural and urban Gini measures vary in the interval $0.17-0.35$ and $0.28-0.38$, respectively. The residual component consists of about 9 per cent to 37 per cent of the overall inequality. Mishra and Parikh suggest that policies to reduce inequalities should be concentrated on reducing the within state urban and rural inequalities simultaneously.

\section{Inequality-poverty-growth relationship}

There has been a great interest in quantifying the relative contribution of economic growth and redistribution to changes in poverty. The objective is to know whether the growth and shift in income distribution helped or hurt the poor population during period of economic expansion or contraction. Datt and Ravallion (1992) decomposed changes in poverty $(P)$ measures into three components:

$$
\begin{aligned}
& P_{t+n}-P_{t}=G(t, t+n ; r)+D(t, t+n ; r)+R(t, t+n ; r) \\
& \quad \equiv\left[P\left(z / \mu_{t+n}, L_{r}\right)-P\left(z / \mu_{t}, L_{r}\right]+\left[P\left(z / \mu_{r}, L_{t+n}\right)-P\left(z / \mu_{r}, L_{t}\right]+R(t, t+n ; r)\right.\right.
\end{aligned}
$$

where $G($.), $D($.) and $R($.) are growth, redistribution and residual components, $t, t+n$ and $r$ refer to the initial, terminal and reference dates, $z$ is poverty line, $\mu$ mean income and $L$ Lorenz curve. The growth component is defined as the change in poverty due to a change in the mean income holding the Lorenz curve constant at some reference level. The redistribution component is defined as the change in the Lorenz curve while keeping the mean income constant at the reference level. The residual vanishes if the mean income and Lorenz curve remain constant over the decomposition period. The

\footnotetext{
${ }^{6}$ An interesting study examining the performance of Indian regions in the areas of health and education and the role of government expenditure in promoting non-income objectives during 1970-1990 is by Dutta, Panda and Wadhwa (1997). Regions are found to differ in performance. The correlation between per capita incomes and performance levels in health (measured as infant and child mortality achievement) or education (measured as achievement in primary to high school) indices is low. The relative position of the states indicates stagnant patterns of human development at the interstate level. Regression analysis indicates that expenditure is an important determinant of level of achievement in health and education sectors. Poverty alleviation programs target often only at the level of the state. For mapping of poverty at more disaggregate level like the districts level see Bigman and Srinivasan (2002). This improves their coverage and reduces the leakage to non-poor sub-groups and the program costs.
} 
method is illustrated with analysis of poverty alleviation in India and Brazil during 1977-1988. Results show that growth and redistributional effects on poverty (measured as head count, poverty gap and Foster-Greer-Thorbecke (FGT) index) were different and uneven across sectors and over time in both countries. India's urban sector contributed to a rising share of aggregate poverty. The distributional shifts and economic growth have aided poverty alleviation in India.

The inequality-poverty-growth relationship can be studied by using other methods rather than decomposition method described above. To mention an example, Jha (2000) examines the empirical relationship between inequality, poverty and growth in India using data on consumption from the $13^{\text {th }}$ to the $53^{\text {rd }}(1957-1997)$ rounds of the national Sample Survey. He computes Gini coefficient and measures of poverty for urban/rural and over time. Inequality is increased over time but poverty has declined only marginally post the reform period, 1990-1991. The rise in inequality is explained by increased capital intensity in production, drop in the rate of labour absorption, and the rapid growth of the service sector. Changes in the capital intensity have resulted in a shift in the distribution of income from wages to profits. The rise in inequality has reduced the poverty-reducing effects of higher growth. The macroeconomic stabilisation and structural adjustment reforms ${ }^{7}$ which begins in 1990-1991 have also been characterised as widening regional inequality. To study the behaviour of inequality over time in separate urban and rural regression the Gini coefficient is regressed on a number of determinants as follows:

$$
G I N I_{i t}=\beta_{i}+\beta_{H C R} H C R_{i t}+\beta_{M C} M C_{i t}+\beta_{M C 2} M C_{i t}^{2}+\varepsilon_{i t}
$$

where the subscript $i$ and $t$ denote state and time periods, $H C R$ and $M C$ are head count ratio and real mean consumption. Inequality at the urban is higher than rural and economic growth implies a shift in the population from rural to urban. The gradual nature of the reform process combined with high job security has reduced the negative impact of inequality. Statistical convergence among states in terms of inequality, poverty and consumption is weak. This is tested using Kendall's index of rank concordance and regression analysis. The coefficient of concordance is written as:

$$
C C_{j}=\left[\sum_{j} R_{j}-\bar{R}\right]^{2} / \frac{1}{12}\left(T^{2}\right) N\left(N^{2}-1\right)
$$

where $R_{j}$ is rank of state $j, T$ and $N$ are the number of years and states. The growth has increased inequality with the reform. In some states with poor growth performance inequality has constrained their economic growth. Rapid economic growth combined with a redistributive policy that does not make the distribution of consumption further skewed is found to be an optimal policy measure.

\section{Inequality and polarisation}

Chakravarty and Majumder (2001) explore the possibility of using different ethical indices of inequality to generate alternative indices of polarisation. The index of polarisation measures the extent of decline on the middle class. Their numerical

\footnotetext{
${ }^{7}$ The economic reform program in India involved fiscal consolidation and stabilisation, industrial policy and foreign investment, trade and exchange rate policies, tax reform, public sector policy, fiscal sector policy, agricultural sector reform, labour market reform, and complementary social measures.
} 
illustration is based on Indian statewise household expenditure data for the period $1987 / 88$ and 1993/94. Monthly per capita total expenditure from 6 states is taken as a proxy for income. Two indices including the Wolfson index and a new general ethical index is suggested and applied to compute polarisation for rural and urban India. The Wolfson index is related to the new general index corresponding to the Gini welfare function. It is established that all inequality indices may be employed to produce alternative indices of polarisation. In several states inequality and polarisation have gone down. In some states polarisation increased in urban sector over the period. In general the equality component of polarisation dominates the inequality component. Inequality and polarisation are found to differ by state, sector and develop differently over time. The relative indices of polarisation which are dependent on income shares are developed in Chakravarty, Majumder and Roy (2002) to form an absolute polarisation index which depends on absolute income differentials. Numerical illustration of the results is based on the Indian data presented above for the period 1993/94. Results suggest that inequality and polarisation are not the same issue in income distribution analysis.

\section{Summary of regional inequality in India}

The data quality underlying inequality and poverty analysis in India qualitatively seem to be much better than those of the Russia Federation. Many Indian studies discuss both inter-regional and intra-regional inequality. The latter is further decomposed into urban and rural components. Results suggests that policies to reduce inequality should be concentrated on reducing the within state urban and rural inequalities simultaneously. A decomposition of changes in poverty shows that growth and redistribution effects on poverty were different and uneven across sectors and over time. The urban sector contributed to raising share of aggregate poverty. The distributional shifts and economic growth have aided poverty alleviation. Changes in capital intensity have resulted in a shift in distribution of income and rise in inequality following macroeconomic stabilisation and structural adjustment reforms. This in turn has reduced the poverty reducing effects of economic growth. To make growth more pro-poor the rapid economic growth must be combined with the better redistributive policies. Polarisation differs by states, sectors and it has developed differently over time.

\section{REGIONAL INEQUALITY IN USA}

The Panel Study of Income Dynamics (PSID) has intensively been used for the analysis of income inequality and income distribution in US. PSID is a nationally representative longitudinal study of about 8000 families in US. The same families and individuals are followed over time since its introduction in 1968. On an annual basis information is collected on economic, health and social behaviour. More information about the data is found at http://psidonline.isr.umich.edu/.

\section{South, Non-South and regional income distribution}

Piketty and Saez (2003) studied the long-run dynamics of income inequality in US during 1913-1998 with reference to wages, income and capital gain shares. Progressive taxation on capital prevented the recovery of top capital incomes following the 
depression and wars. Top wages share recovered in late 60s. Declines in progressive taxation could result in high wealth concentration.

The US South has historically had both lower incomes and greater inequality than the Non-South. Migration of skilled and highly educated manpower and industrial relocation has narrowed the regional differences and reduced the persistence in income disparity. Bishop, Formby and Thistle (1992) present evidences that reveal convergence of the South and Non-South income distributions taken place following the changes in the income distributions in 1969-1979. The basic income measure is household income from all sources in 1969 and 1979. It is adjusted for regional price differences by using constructed regional cost-of-living estimates. Results show that in 1969 Non-South rank-dominates the South but in 1970s household income distribution in the South and Non-South converges at all decile points except the very bottom one in 1979. Tests of South versus Non-South mean income equality is performed.

At a somewhat disaggregate regional level Loewy and Papell (1996) further developed the Carlini and Mills (1993) stochastic convergence formulation of a time series notion of convergence to investigate thr convergence among eight US regions during the 19291990 period. Loewy and Papell incorporate endogenously determined break points. Regions represent a set of economies where conditions underlying convergence in per capita income are satisfied. The negative relationship between initial log per capita income and the rate of growth conditioning on the factors determining the steady state is the evidence of convergence. By using US regional data conditional convergence is tested. ${ }^{8}$ In seven out of eight regions the unit root hypothesis is rejected. The results indicate that regional incomes are stochastically converging to that of the nation as predicted by the neoclassical growth model.

\section{Interstate income inequality}

Trends in interstate income inequality using a panel of the 48 US states for the 19601990 period is examined by Partridge, Rickman and Levernier (1996). The focus is on the estimation of a multitude of potential causes of the sharp increase in US income inequality. The following empirical model for family income inequality in state $i$ at time period $t$ written as:

$$
G I N I_{i t}=f\left(E C O N_{i t}, D E M O G_{i t}, I N S T_{i t}\right)+\mu_{r}+\lambda_{t}+\varepsilon_{i t}
$$

is estimated. Where ECON, DEMOG and INST are vectors of economic, demographic, and institutional variables that vary cross states and over time, $\mu, \lambda$ and $\varepsilon$ are regional specific, time-specific (skill-biased technological change and common trend component) and error term. Partridge, Rickman and Levernier find that greater international migration, greater metropolitan share of population, increased percent households headed by females, greater female labour market participation affected reducing low-skilled wages and advanced stages of economic development increase income inequality while greater labour-force participation rate decreases inequality. Unionisation did not affect state level income inequality. There is little evidence that technological change increases income inequality. The estimated fixed state effects suggest that the other institutional and cultural differences and their changes over time may be partly responsible for the increase in income inequality.

\footnotetext{
${ }^{8}$ The condition is often made on human capital, physical capital and population growth as determinants (see Mankiw, Romer and Weil 1992).
} 
Price levels differ among regions within a country for many reasons such as transportation distance. Using constructed state-level price data Black and Dowd (1997) examined real interstate personal income equality in US. The real income inequality index for the U.S. states is:

$$
I=\sum_{i=1}^{n} p_{i} \ln \left(p_{i} / y_{i}\right)=\sum_{i=1}^{n}\left(\frac{P O P_{i}}{P O P_{U S}}\right) \ln \left(\frac{\left(P O P_{i} / P O P_{U S}\right)}{\left(y_{i} / P I_{i}\right) /\left(y_{U S} / P I_{U S}\right)}\right)
$$

where $p_{i}$ and $y_{i}$ are the shares of state $i$ in the total population and total personal income, and $P I_{i}$ is state level price deflator. The data cover 48 continental states and the district of Colombia for the period 1963-1989. The results show that real income inequality is 53 per cent larger than its nominal counterpart. Regression of real and nominal income inequalities $(I)$ on a trend and squared trends:

$$
I_{t}^{R}=\beta_{0}+\beta_{1} T+\beta_{2} T^{2}+u_{t}^{R} \quad \text { and } \quad I_{t}^{N}=\alpha_{0}+\alpha_{1} T+\alpha_{2} T^{2}+u_{t}^{N}
$$

The above equation shows that both income inequalities have steadily increased over time.

\section{Factor influencing inequality}

Several factors which affect inequality are discussed above. Income inequality affects the welfare of individuals and households in different ways. A survey of the debate over the association between health (measured as mortality), inequality and economic development is given by Deaton (2001). Deaton and Lubotsky (2002) argue that the (positive) correlation between mortality and income inequality across the cities and states of the US is confounded by the effects of racial composition. Empirical results based on Compressed Mortality Files (CMF) from 1968 to 1994 show that conditional on the fraction of black, neither city nor state mortality rates are correlated with income inequality. The high rate of mortality where the fraction of black is higher is because white mortality is higher in such place, not because of higher mortality rate or lower black incomes. The results are robust to conditioning on income, education and unobservable state effects.

Availability of microdata has resulted in better investigation of determinants of inequality. Zandvakili (1999 and 2000) investigates the effects of race in conjunction with age, education and marital status on income inequality among female heads of household. Results using PSID data for the period 1978-1986 show that short-run inequality has generally increased influenced by the existence of transitory components. The long-run inequality is declining due to smoothing of the transitory component. Race and education are found to explain over one-third of observed inequality. Age and marital status also were possible factors influencing inequality. Most movements occur within each group and there is an indication of permanent inequality among female heads of household. Moffitt and Gottschalk (2002) find that the variance of permanent component of male earnings in US increased in the late 1970s and in the 1980s, while the variance of transitory component rose in the 1980s but declined in the 1990s. Zandvakili and Mills (2001) find that social security income and income taxes reduce income inequality in a given year, but there are no significant changes over time. Income transfers have minimal impact in reducing inequality. 
Conventional inference procedures like those above assume independent samples. Inference tests are conducted based on calculated standard errors for estimates of inequality indices. Zheng and Cushing (2001) propose a method for correction of sample dependency in testing inequality indices. Simulations and applications to the Current Population Surveys (CPS) and PSID data indicates that failure to correct for sample dependency may increase the standard error by 3.3 to 17.1 per cent. Recently Maasoumi and Heshmati (2003) employed the extended Kolmogorov-Smirnov tests of first and second order stochastic dominance to examine the dynamic evolution of disposable and gross incomes for several household groups ${ }^{9}$ in the PSID panel data at several points from 1968 to 1997. They find a surprising number of strong rankings, both between groups and over time, and in both gross and disposable incomes.

\section{Summary of regional inequality in USA}

Access to high quality household data covering long period for US allows analysis of dynamics of income inequality and distribution. Analysis of income is performed at different levels. US South historically had both lower incomes and greater inequality than the Non-South. The income per capita is however converging over time. At the regional level, incomes are stochastically converging the level of the nation. There is significant interstate income inequality. Greater international migration, increased metropolitan share of population, changes in family structure, increased share of female headed households, female labour participation and institutional and cultural differences increased income inequality, while greater labour force participation reduced inequality. Race, education, age and marital status are key factors affecting inequality in US. It is important to distinguish between transitory and permanent components of inequality. Short-run inequality is influenced by the transitory shocks, while long-run inequality is declining due to smoothing of the transitory component.

\section{REGIONAL INEQUALITY IN A SELECTION OF SMALLER COUNTRIES}

It has not been possible to trace regional studies of income distribution and inequality covering smaller but yet populated developing and transition countries. At the absence of such few single country studies covering different regions and levels of development including Colombia, Indonesia, Philippines, South Africa, Zambia, and Poland are presented below where by looking at various dimensions. The inequality can be decomposed into different underlying components.

\section{Colombia}

Birchenall (2001) discuss the recent increase in income inequality and dynamic aspects of income and educational mobility in Colombia for 1976 to 1996. Human capital accumulation reduced the dispersion of income distribution leading to a declining mobility in 1983 to 1990 . Trade liberalisation increased the wage differential of skilled workers. It increased inequality, induced polarisation and lead to high mobility. The relationship between inequality and polarisation is dynamically mutual, and in long-run bi-directional. Fixed investment growth has little impact on polarisation. This indicates

\footnotetext{
${ }^{9}$ The household head characteristics that Maasoumi and Heshmati (2003) condition on include: age, marital status, working status, race, gender, occupation, number of children, level of education, length of unemployment, and geographical mobility.
} 
that the deterioration of income distribution being attributed to the trade liberalisation process. The results suggest that the polarisation of income measured as a modified version of the Esteban-Ray index (see equation 10). This variable most strongly and dynamically correlated with income inequality and GDP growth.

\section{Indonesian Java}

Cameron (2000) uses the method of DiNardo et al. (1996) modified to decompose changes in distribution of per capita household income of 20000 households in Java between 1984 and 1990. The changes are related to the ageing population, higher educational attainment, movement out of agriculture, changes in income within industry and age/education categories. The results indicate that the welfare cost of increasing income inequality was more than offset by the social welfare gain from higher incomes. Poverty reduction measures have caused inequality to increase. Inequality increased from 0.40 in 1984 to 0.42 in 1990. Increase in non-agricultural incomes, movement out of agriculture and increased educational attainment increases inequality. However, the growth in income has partially compensated for growing inequality.

\section{Philippines}

The ultimate objective of concern for economic policy is the well-being of individuals. However, in practice the significance of intra-household inequality and distribution of resources within a household has been neglected. There is little experience on the impact of intra-household inequality on the conventional measures of inequality and poverty. Haddad and Kanbur (1997) present a framework where the inequality is decomposed into intra- and inter-household inequality components. In the illustration it accounts for intra-household inequality in nutritional status and applied it to food consumption data from Philippines. There are three variables of interest: individual calorie adequacy $\left(I C A_{i}\right)$, mean $I C A$ within the household $\left(M I C A_{i}\right)$, and household calorie adequacy $\left(H C A_{h}\right)$ defined as:

$$
M I C A_{i}=\frac{1}{n_{h}} \sum_{i=1}^{n_{h}} I C A_{i} \text { and } H C A_{h}=\sum_{i=1}^{n_{h}} C I_{i} / \sum_{i=1}^{n_{h}} C R_{i}
$$

where $C I_{i}$ is calorie intake, $C R_{i}$ is calorie requirement of individual $i$, and $n_{h}$ is number of individuals in household $h$. The data covers a sixteen month period in 19841985 and 448 households comprising 2880 individuals. The results based on the three variables of interest and five commonly used measures of inequality ${ }^{10}$ suggest that the neglect of intra-household inequality might result in an understatement of inequality and poverty. The errors are of the order of 30 per cent or more but it might not reverse the rankings of policy-relevant socio-economic groups ranked by inequality and poverty.

\section{South Africa}

From a policy perspective the relative importance of income sources is crucial in analyses of inter-household inequality and poverty. Recent advances in decomposition of Gini coefficient by income components (Duro and Esteban 1998; Zandvakili 1999;

\footnotetext{
${ }^{10}$ The five inequality measures are: coefficient of variation, $\log$ variance, Gini coefficient, the Theil's second measure, and the Atkinson equally distributed equivalent measure with inequality aversion parameter equal to 2 .
} 
Cameron 2000; Goerlich-Gisbert 2001; Biewen 2002) allows for assessment of changes in income components on the Gini coefficient. Liebbrandt, Woolard and Woolard (2000) following Lerman and Yitzhaki (1985) applied such a decomposition technique to 8691 South African households data for the rural former homeland areas observed in 1993. Here the income sources include remittances, wage income, capital income, state transfers, agriculture and self-employment. Wage income is found to be the most important income component and source of inequality. Hence policies increases average income and reducing unemployment can have major impact on the distribution of income with positive net welfare effect. The method could be useful tool in assessment of the South African government's post-apartheid economic and social policies.

The high inequality of South Africa has been often explained by the racial legacy. Liebbrandt and Woolard (2001) show that between race contributions to inequality have declined, although the within each race group inequality widened during 1975 to 1996. Income is measured as per adult equivalent. The overall inequality using the same method as mentioned above is decomposed into sectors, different sub-groups and income sources. The results suggest the existence of complex patterns of inequality generation.

\section{Zambia}

Determinants of poverty, inequality and growth in Zambia during the 1990s is examined by McCulloch, Baulch and Cherel-Robson (2003). Five different measures of inequality (coefficient of variation, Gini coefficient, standard deviation of logs, Theil's entropy measure and Theil's mean log deviation) and three measure of poverty (headcount, poverty gap and squared poverty gap) are used. Poverty line is locally defined based on the cost of basic needs approach and also based on the World Banks US\$1/per day. The empirical results are based on three nationally representative household surveys from 1991, 1996 and 1998. During this period Zambia implemented radical programmes of structural adjustment to boost long-term growth and poverty reduction. Income is defined as the total consumption expenditure. Poverty rate, changes in poverty and inequality is reported over time by various measures and each decomposed into urban, rural and nine provinces. Results show that growth has been weak and poverty has increased dramatically in the urban areas in 1991-1996. There was a reduction in poverty concentration in rural areas between 1996 and 1998. Rural Gini coefficient declined from 0.62 to 0.48 and the urban from 0.47 to 0.43 . The authors outline four policy lessons to be learned from the 1990s: (i) reforms should be adjusted to account for external shocks, (ii) internal liberalisation can have a poverty impact as external liberalisation, (iii) protection of social expenditure during stabilisation and adjustment be combined with maintaining high level of expenditure, and (iv) development of social safety net to protect sub-groups suffering from price changes.

\section{Poland}

The impact of transition on earnings inequality by using data across 49 Polish regions during 1994-1997 is estimated by Sibley and Walsh (2002). The regions are divided into 6 groups based on the taxonomy of the inherited public infrastructure. ${ }^{11}$ Nine

\footnotetext{
${ }^{11}$ Four indicators are used in ranking the regions: (i) number of Telephones and (ii) number of Fax Machines in a region per 1000 inhabitants, (iii) Number of Railways and (iv) Number of Public Roads in a region per $100 \mathrm{~km}$ squared.
} 
measures of earnings inequality are used. ${ }^{12}$ Results indicate that earnings inequality is higher in regions that are advanced in restructuring. At the national level there is evidence of a relationship between rapid growth and rise in earnings inequality. Aggregate inequality is not changing much over time, but the between region inequality is widening over time. The range of regional inequality is $0.21-0.25$ and $0.19-0.27$ in 1994 and 1997, respectively.

Keane and Prasad (2002) analyse the evolution of inequality in Poland during the economic transition 1990-1997 by using household budget survey data. The results indicate that income and consumption inequality in 1997 is lower than in 1990-1992. Social transfer mechanism including pensions played an important role in dampening the increase in overall inequality. Cross country evidence from the transition economies suggest that redistribution that reduces income inequality can also enhance economic growth.

\section{Summary of regional inequality in selection of smaller countries}

Variations in income inequality in a selection of smaller countries mainly by other dimensions than regional were reviewed. In the case of Colombia the deterioration of income distribution is attributed to the process of trade liberalisation. Polarisation of income is correlated with income inequality and GDP growth. The changes in the distribution of income in Java is related to the ageing population, higher educational attainment, industrial structure, changes in income within industry and age/education categories. Growth in income partially compensated for growing inequality. Evaluation of economic policy in Philippines show that in practice the significance of intrahousehold inequality and distribution of resources within a household has been neglected resulting in understatement of inequality and poverty. Research analysing inter-household inequality and poverty in South Africa point to the importance of source of income as determinant of income inequality. The between racial group inequality has declined but the within racial group has increased. Stabilisation and adjustment programmes in Zambia resulted in reduction in concentration of poverty and declining inequality. An examination of the impact of transition on income inequality in Poland indicates a positive relationship between rapid economic growth, advances in restructuring and rise in earnings inequality. The social transfer mechanism including pensions dampened increases in overall inequality. Redistribution that enhances inequality can enhance growth.

\section{THE WIID DATA}

The data underlying analysis in the next section are obtained from the WIDER World Income Inequality Database (WIID). WIID contains information on income inequality, income shares, and a number of variables indicating the source and coverage of data for 146 countries. The countries are observed on an irregular basis mainly covering the period post 1950 until 1998. Here we focus on the inequality among selected large

\footnotetext{
12 The nine earnings inequality measures include: relative mean deviation, coefficient of variation, standard deviation of logs, Gini index, Mehran index, Piesch index, Kakwani index, Theil entropy index, and mean $\log$ deviation.
} 
countries. At the absence of data at the regional level, we use time series data, although countries are not observed consecutively over time.

The Gini coefficient is measured in percentage points. It is mean of multiple observations for a country in a given year. The multiplicity of observations is due to differences in income definitions, data sources, reference units, and population coverage. Gini coefficient was also calculated adjusted for share of population. Such adjustment is most relevant when aggregating inequality to the global level. However, the population adjusted Gini measure is very sensitive to the exit and entry of countries with large population like China and India.

In order to provide a picture of the distribution of income and inequality we report the first, the last, the period range and the number of years a country is observed. In addition to the mean Gini coefficient, median, minimum, maximum, standard deviation, range and annual changes in Gini are provided in Table 1 for large countries together with mean values for the region where they are located. In Table 2 we report Gini coefficient and population weighted Gini together with distribution of income. The decile observations are transformed to quintile income shares with the objective to make the income distribution comparable across countries and over time. As a second measure of inequality the ratio of the highest to the lowest quintiles are calculated and reported in Table 2.

It should be noted that the point observations are not comparable across countries or for the same country over time. The data incomparability is due to differences in unit of measurement, area and population coverage, and income definitions. There is a trade off between the number of observations and the consistency of the data. Long time series is required to investigate trends in inequality. This is the motivation for our preferences for a maximisation of the number of observations rather than a search for maintaining data consistency.

\section{RESULTS BASED ON THE WIID}

The comparison of income inequality among the four large countries reported in Table 1 show that mean Gini coefficient in China (29.35) and India (34.55) is higher than the regional mean values where the countries are located, while those of Russia (34.14) and US (39.65) are higher than their respective regional means. It is to be noted that the country mean values are based on observations covering different sub-periods.

With the exception of Russia the mean and median values are quite close. However, the standard deviation and range between minimum and maximum Gini values differ greatly among the countries. India (3.63) and US (2.35) shows less dispersion in Gini coefficient over time. The lowest quintile income share in US (0.05) shown in Table 2 is lowest compared to the 0.08-0.09 among the other countries. The low Q1 combined with the high Q5 share (0.43) compared with those of the results of the other countries (0.39-0.43) which are a high Q5/Q1 ratio for US (9.17). The corresponding for other countries is 4.56 (Russia), 4.83 (India) and 5.21 (China).

In Table 3 in addition to Gini coefficient and quintile income shares we report the percentage changes in Gini coefficient as well as the population and per capita incomes over time for the sample of four large countries. The quintile income shares are not reported in some years due to missing observations. The annual changes with the 
exception of US can vary greatly for China, India and Russia reflecting effects of economic crises or shocks to the economy. In case of Russia the large changes are always leading to increasing inequality, while in the cases of China and India large reductions in inequality can be observed in certain periods. The US annual income inequality change with the exception of 1991/92 and 1996/97 is small and not exceeding 10 per cent. The growth in population is highest in India, while the growth in GDP per capita is highest in China followed by US. Worth to mention is that the level of per capita income in US (50573) unadjusted for PPP is more than 15 times of that of China (3192) in 1997. Distinction should be made between relative and absolute values in comparing the four countries with respect to per capita GDP and populations.

The development of Gini coefficient together with quintile income shares and the Q5/Q1 ratio for individual countries are presented in Figures 1 to 4 . In order to make the data levels comparable the Q5/Q1 ratio is divided by 10 and Gini coefficients are reported in decimal form in the 0-1 interval. Furthermore the years where quintile income shares are missing are excluded from the graphs. Only years where all information is available are used in drawing the graphs. However, complete set of data including excluded observations can be viewed in Table 3.

Figure 1 shows that income share of the second and third quintiles in China are declining over time. Shifts in income are taken place mainly among the fourth and fifth quintiles. Inequality show increasing trend post 1985 . The Q5/Q1 ratio is increasing sharply between 1984 and 1989 but it declines from 1992. Inequality in India has declined before 1972 and remained constant until 1994 then increased (see Figure 2). The income share of the first quintile in India has increase during 1950-1967 and 1992 onward. The Gini coefficient follows same temporal patterns as that of the fifth quintile. The Q5/Q1 ratio is declining over time before 1993. The corresponding numbers for Russia (see Figure 3) during 1993-98 are quite stable with the exception of 1995 when major shift in the quintile income share is observed. The similarity with India the US Gini coefficient develops in the same way as income share of the fourth quintile (see Figure 4). Shifts in the income shares are from the second and third quintiles to the fifth quintile. The Q5/Q1 ratio fluctuates greatly post 1980. Finally, development of Gini coefficient for all four countries is shown in Figure 5. The trend in inequality in US, China and Russia is positive, while that of India is negative but variable.

\section{SUMMARY}

Income inequality can be measured at different dimensions and levels of aggregation. In this chapter the within-country income inequality at the regional level was reviewed. Regional inequality in a selection of large countries with regional division is also examined. Here region is equivalent of states, provinces, federation or geographic regions within a country. The empirical results reported here are mainly based on the second half of the $20^{\text {th }}$ century and four large countries including China, Russia, India and USA, as well as a number of smaller developing and transition countries.

China has experienced a rapid economic growth post the economic reform accompanied by an increased inequality. The positive correlation between growth and inequality is in support of Kuznet's U-shaped curve. The level and development of inequality has been different by geographical location and sectors. In a number of studies attempts has been 
made to identify determinants of inequality across different provinces. The inequality is decomposed into components associated with inter and intra-sector and provincial components. Regional equality has improved following openness, marketisation and convergence due to factor mobility. There is indication of regional polarisation driven by structural differences between regions.

Regional inequality and polarisation is of a more serious policy concern in Russia. Heterogeneous economic development, size, ethnic and natural diversity of regions, restructuring policies and economic shocks caused disintegration and widening regional inequality and poverty. Data quality and measurement error also causes biased estimation of the inequality and poverty. A restructuring of the education system is suggested to reduce inequality and to increase mobility.

The study of empirical relationship between growth, inequality and poverty in India shows that inequality is increased but poverty has declined marginally during the post reform period. Both inter-regional and intra-regional inequalities are equally emphasised. Policies that target reduction of inequality should be concentrated on reducing the within state urban and rural inequalities simultaneously. Economic growth and redistribution have aided poverty. However raising capital intensity in production have resulted in shift in the income distribution reducing the effects of economic growth. Rapid economic growth must be combined with pro-poor redistributive policies.

The US South has historically had lower income but higher inequality than the NonSouth. Migration, skill, technology, gender and changing household characteristics affected increased income inequality. State level income per capita is stochastically converging over time to that of the nation. There is significant interstate and intrastate inequality. Race, education, age and marital status are the key factors affecting household income inequalities. Distinction between transitory and permanent components of inequality matters.

Variations in income inequality in a selection of smaller countries show significant degree of heterogeneity in both levels and development over time, as well as other subgroup characteristics dimensions. Empirical results suggest that inequality and poverty alter following various structural adjustment programs affecting the welfare of subgroups differently.

The results of WIID show that inequality in US has increased slightly over time. The trend in inequality in India is negative but variable. There is a positive trend in inequality in China and Russian Federation following their economic reforms. 


\section{REFERENCES}

Acemoglu D. (2002), Cross-country inequality trends, NBER Working Paper No. 8832.

Alesina A. and D. Rodrik (1994), Distributive politics and economic growth, Quarterly Journal of Economics 109, 465-490.

Belbo M. and T. Knaus (2001), Measuring income inequality in Euroland, Review of Income and Wealth 47(3), 301-320.

Biewen M. (2002), Bootstrap inference for inequality, mobility and poverty measurement, Journal of Econometrics 108(2), 317-342.

Bigman D. and P.V. Srinivasan (2002), Geographical targeting of poverty alleviation programs: methodology and applications, Journal of Policy Modeling 24(3), 237255.

Birchenall J.A. (2001), Income distribution, human capital and economic growth in Colombia, Journal of Development Economics 66, 271-287.

Bishop J.A., Formby J.P. and P.D. Thistle (1992), Convergence of the South and NonSouth income distribution, 1969-1979, The American Economic Review 82(1), 262-272.

Black D.C. and M.R. Dowd (1997), Measuring real interstate income inequality in the United States, Economics Letters 56, 367-370.

Bourguignon F. and C. Morrisson (2002), Inequality among world citizens: 1820-1992, American Economic Reviews 92(4), 727-747.

Cameron L.A. (2000), Poverty and inequality in Java: examining the impact of the changing age, educational and industrial structure, Journal of Development Economics 62, 149-180.

Canagarajah S., C. Newman and R. Bhattamishra (2001), Non-farm income, gender, and inequality: evidence from rural Ghana and Uganda, Food Policy 26, 405-420.

Carlini G.A. and L.O. Mills (1993), Are U.S. regional income converging? A time series analysis, Journal of Monetary Economics 32, 335-346.

Chakravarty S.R. and A. Majumder (2001), Inequality, polarisation and welfare: theory and applications, Australian Economic Papers 40(1), 1-13.

Chakravarty S.R., A. Majumder and S. Roy (2002), A treatment of absolute indices of polarisation, Unpublished manuscript, Indian Statistical Institute, Calcutta, India, Presented at the International Workshop on Income Distribution and Welfare, Bocconi May 30 to June 22002.

Cheng Y-S. (1996), A decomposition analysis of income inequality of Chinese rural households, China Economic Review 7(2), 155-167.

Commander A., A Tolstopiateniko and R. Yemtsov (1999), Chanells of redistribution: inequality and poverty in the Russian transition, Economics of Transition 7(2), 411-447.

Cornia G.A. and S. Kiiski (2001), Trends in income distribution in the post WWII period: evidence and interpretation, WIDER Discussion Paper 2001/89, Helsinki: UNU/WIDER. 
Cowell F.A., F.H.G. Ferreira and J.A. Lichtfield (1998), Income distribution in Brazil 1981-1990: parametric and non-parametric approaches, Journal of Income Distribution 8(1), 63-76.

Datt G. and M. Ravallion (1992), Growth and redistribution components of changes in poverty measures: A decomposition with applications to Brazil and India in the 1980, Journal of Development Economics 38, 275-295.

Deaton A. (2001), Health, inequality, and economic development, NBER Working Paper 8318.

Deaton A. and D. Lubotsky (2002), Mortality, inequality and race in American cities and states, Social Science \& Medicine 55(6), 1139-1153.

Demurger S., J.D. Sachs, W.T. Woo, S. Bao, G. Cheng and A. Mellinger (2002), Geography, Economic Policy, and regional development in China, NBER Working Paper 8897.

DiNardo J., N.M. Fortin and T. Lemieux (1996), Labor market institutions and the distribution of wages, 1973-1992: a semiparametric approach, Econometrica 64,5, 1001-1044.

Dutta B., M. Panda and W. Wadhwa (1997), Human development in India, in S. Subramanian (ed) Measurement of inequality and poverty, Oxford University Press, pp. 329-358.

Earle J. and K. Sabirianova (2001), Understanding wage arrears in Russia, Journal of Labor Economics 20, 661-707.

Eastwood R. and M. Lipton (2000), Rural-Urban dimensions of inequality change, WIDER Working Papers 2000/200, Helsinki: UNU/WIDER.

Esteban J-M. D. Ray (1994), On the measurement of polarization, Econometrica 62(4), 819-851.

Fan C.S., J. Overland and M. Spagat (1999), Human capital, growth and inequality in Russia, Journal of Comparative Economics 27(4), 618-643.

Fedorov L. (2002), Regional inequality and regional polarisation in Russia, 1990-99, World Development 30(3), 443-456.

Flemming J. and J. Micklewright (2000), Income distribution, economic systems and transition, in Atkinson A.B. and Bourguignon F. (Eds), Handbook of Income Distribution, Volume 1, North Holland, chapter 14, pp. 843-918.

Georlich-Gisbert F.J. (2001), On factor decomposition of cross-country income inequality: some extensions and qualifications, Economics Letters 70, 303-309.

Gottschalk P. and T.M Smeeding (1997), Cross-national comparisons of earnings and income inequality, Journal of Economic Literature 35, 633-687.

Gottschalk P. and T.M. Smeeding (2000), Empirical evidence on income inequality in industrialized countries, in Atkinson A.B. and Bourguignon F. (Eds), Handbook of Income Distribution, Volume 1, North Holland, chapter 5, pp.261-308.

Gustafsson B. and L. Shi (2001a), The anatomy of rising earnings inequality in Urban China, Journal of Comparative Economics 29(1), 118-135. 
Gustafsson B. and L. Shi (2001b), The effects of transition on the distribution of income in China: a study decomposing the GINI coefficient for 1988 and 1995, Economics of Transition 9(3), 593-617.

Gustafsson B. and L. Shi (2002), Income inequality within and across counties in rural China 1988 and 1995, Journal of Development Economics 69(1), 179-204.

Gustafsson B., L. Shi, L. Nivorozhkia and K. Katz (2001), Rubles and Yuan: wage functions for urban Russia and China at the end of the 1980s, Economic Development and Cultural Change 50(1), 1-17.

Gustafsson B. and W. Zhong (2000), How and why has poverty in China changed? A study based on microdata for 1988 and 1995, The China Quarterly 164, 983-1006.

Haddad L. and R. Kanbur (1997), How serious is the neglect of intra-household inequality?, in S. Subramanian (ed) Measurement of inequality and poverty, Oxford University Press, pp. 106-127.

Heshmati A. (2004a), A review of decomposition of income inequality, IZA Discussion Paper 2004:1121.

Heshmati A. (2004b), The World Distribution of income and income inequality, Unpublished manuscript.

Heshmati A. (2004c), Continental and sub-continental income inequality, Unpublished manuscript.

Iacoviello M. (1998), Inequality Dynamics: evidence from some European countries, Working Paper No. 191, Maxwell School of Citizenship and Public Affairs, Syracuse University.

Ivaschenko O. (2002), Growth and inequality: evidence from transitional economics, CESIFO Working Paper 2002:746.

Jha R. (2000), Reducing poverty and inequality in India: Has liberalization helped?, Working Papers 2000/204, Helsinki: UNU/WIDER.

Jian T., J.D. Sachs and A.M. Warner (1996), Trends in regional inequality in China, China Economic Review Volume 7(1), 1-21.

Kakwani N. and M. Krongkaew (2000), Introduction: Economic growth, poverty and income inequality in the Asia-Pacific region, Journal of the Asia Pacific Economy 5(1/2), 9-13.

Kanbur R. and X. Zhang (1999), Which regional inequality? The evolution of ruralurban and inland-coastal inequality in China from 1983 to 1995, Journal of Comparative Economics 27(4), 686-701.

Keane M.P. and E.S Prasad (2002), Inequality, transfers and growth: new evidence from the economic transition in Poland, The Review of Economics and Statistics 84(2), 324-341.

Khan A.R. and C. Riskin (2001), Inequality and poverty in China in the age of globalization, Oxford University Press.

Kuznets S. (1955), Economic growth and income inequality, American Economic Review 45, 1-28. 
Lee J. (2000), Changes in the source of China's regional inequality, China Economic Review 11(3), 232-245.

Lehmann H. and J. Wadsworth (2001), Wage arrears and the distribution of earnings in Russia, IZA Working Paper 2001:410.

Lehman H., Wadsworth J. and A. Aquisti (1999), Crime and punishment: job security and wage arrears in the Russian Federation, Journal of Comparative Economics 27, 595-617.

Lerman R.I. and S. Yitzhaki (1985), Income inequality effects by income source: a new approach and applications to the United States, Review of Economics and Statistics 67(1), 151-156.

Liebbrandt M. and I. Woolard (2001), The labour market and household income inequality in South Africa: existing evidence and new panel data, Journal of International Development 13, 671-689.

Liebbrandt M., C. Woolard and I. Woolard (2000), The contribution of income components to income inequality in the rural former homelands of South Africa: a decomposable Gini analysis, Journal of African Economies 9(1), 79-99.

Lindert P.H. and J.G. Williamson (2001), Does globalization make the World more unequal?, NBER Working Paper 2001:8228.

Loewy M.B. and D.H. Papell (1996), Are US regional incomes converging? Some further evidence, Journal of Monetary Economics 38, 587-598.

LondoNo J.L. and M. Szekely (2000), Persistent poverty and excess inequality: Latin America, 1970-1995, Journal of Applied Economics III(1), 93-134.

Luttmer E.F.P. (2001), Measuring poverty dynamics and inequality in transition economies: disentangling real events from noisy data, The World Bank Policy Research Working Paper 2001:2549.

Maasoumi E. and A. Heshmati (2003), Evaluating dominance ranking of PSID incomes by various household characteristics, Unpublished manuscript.

Mahler V.A. (2001), Economic globalization, domestic politics and income inequality in the developed countries: a cross-national analysis, Luxembourg Income Study Working Paper 273, Luxembourg.

Mankiew N.G., D. Romer and D.H. Weil (1992), A contribution to the empirics of economics growth, The Quarterly Journal of Economics 107, 407-438.

McGulloch N., B. Baukh and M. Cherel-Robson (2003), Poverty, inequality and growth in Zambia during the 1990s, In: van der Hoeven R. and A. Shorrocks, Perspectives on Growth and Poverty United Nations University Press.

Milanovic B. (2001), World income inequality in the second half of the $20^{\text {th }}$ century, World Bank, Development Research Group.

Milanovic B. (2002), True world income distribution, 1988 and 1993: First calculation based on household surveys alone, Economic Journal 112(476), 51-92.

Milanovic B. and S. Yitzhaki (2001), Decomposing world income distribution: does the world have a middle class?, WB 2001:2562. 
Mishra P. and A. Parikh (1997), Distributional inequality in Indian states, Journal of Income Distribution 7(1), 89-108.

Moffitt R.A. and P. Gottschalk (2002), Trends in the transitory variance of earnings in the United States, The Economic Journal 112, March C68-C73.

Morduch J. and T. Sicular (2002), Rethinking inequality decomposition, with evidence from rural China, Economic Journal 112(476), 93-106.

Park A., S. Wang and G. Wu (2002), Regional poverty targeting in China, Journal of Public Economics 86, 123-153.

Partridge M.D., D.S. Rickman and W. Levernier (1996), Trends in U.S. income inequality: evidence from a panel of states, The Quarterly Review of Economics and Finance 36(1), 17-37.

Perron P. (1989), The great crash, the oil price shock and the unit root hypothesis, Econometrica 57(6), 1361-1401.

Persson T. and G. Tabellini (1994), Is inequality harmful for growth? American economic Review 84, 600-621.

Piketty T. and E. Saez (2003), Income inequality in the United States, 1913-1998, Quarterly Journal of Economics CXVIII(1), 1-39.

Quah D. (1999), Some dynamics of global inequality and growth, London School of Economics, London School of Economics, mimeo.

Quah D. (2002), One third of the world's growth and inequality, Economics Department, CEPR Discussion Paper 2002:3316.

Ram R. (1995), Economic development and income inequality: An overlooked regression constraint, Economic Development and Cultural Change 43(2), 425434.

Ravallion M. (1998), Does aggregation hide the harmful effects of inequality on growth?, Economics Letters 61, 73-77.

Ravallion M. and S. Chen (1999), When economic reform is faster than statistical reform: measuring and explaining income inequality in Rural China, Oxford Bulletin of Economics and Statistics 61, 33-56.

Ritakallio V-M. (2001), Trends of poverty and income inequality in cross-national comparison, Luxembourg Income Study Working Paper No. 272.

Sala-i-Martin X. (2002), The world distribution of income (estimated from individual country distribution), NBER Working Paper 8933.

Schultz T.P. (1998), Inequality in distribution of personal income in the world: how it is changing and why, Journal of Population Economics 11(3), 307-344.

Shi L. (2001), Changes in poverty profile in China, WIDER Discussion Paper 2001/21, Helsinki: UNU/WIDER.

Shorrocks A. and S. Kolenikov (2001), Poverty trends in Russia during the transition, Unpublished manuscript. 
Sibley C.W. and P.P. Walsh (2002), Earnings inequality and transition: a regional analysis of Poland, IZA Discussion Paper No. 2002:441.

Svedbery P. (2002), Income distribution across countries: how is it measured and what do the results show?, IIES Seminar Papers, SWoPEc 2002:698.

Tsui K-Y. (1993), Decomposition of China's regional inequalities, Journal of Comparative Economics 17(3), 600-627.

Tsui K-Y. and Y. Wang (1998), Polarisation ordering and new classes of polarisation indices, memo, The Chinese University of Hong Kong.

Wan G.H. (2001), Changes in regional inequality in rural china: decomposing the Gini index of income sources, The Australian Journal of Agricultural and Resource Economics 45(3), 361-381.

Wan G.H. (2002a), Regression-based inequality decomposition: Pitfalls and a solution procedure, WIDER Discussion Paper 2002/101, Helsinki: UNU/WIDER.

Wan G.H. (2002b), Income inequality and growth in transition economies: are nonlinear models needed?, WIDER Discussion Paper 2002/104, Helsinki: UNU/WIDER.

Wolfson M.C. (1994), Conceptual issues in normative measurement: when inequalities diverge, American Economic Review 84(2), 353-358.

Wood A. (1997), Openness and wage inequality in developing countries: the Latin American challenge to East Asian continental wisdom, World Bank Economic Review 11(1), 33-57.

Xu L.C. and H-F. Zou (2000), Explaining the changes of income distribution in China, China Economic Review 11, 149-170.

Yemtsov R. (2002), Quo Vadis: inequality and poverty dynamics across Russian regions in 1992-2000, Paper prepared for WIDER project meeting Microsimulation of Tax Benefit Reform in Russia, 2-3 August 2002, Helsinki.

You I. (1998), Income distribution and growth in East Asia, Journal of Development Studies 34(6), 000-000.

Zandvakili S. (1999), Income inequality among female heads of households: racial inequality reconsidered, Economica 66, 119-133.

Zandvakili S. (2000), Dynamics of earnings inequality among female-headed households in the United States, Journal of Socio-Economics 29, 73-89.

Zandvakili S. and J.A. Mills (2001), The distributional implications of tax and transfer programs in US, The Quarterly Review of Economics and Finance 41, 167-181.

Zhang X. and R. Kanbur (2001), What difference do polarisation measures make? An application to China, Journal of Development Studies 37(3), 85-98.

Zhang Z., A. Liu and S. Yao (2001), Convergence of China's regional incomes, 1952-1997, China Economic Review 12(2/3), 243-258.

Zheng B. and B.J. Cushing (2001), Statistical inference for testing inequality indices with dependent samples, Journal of Econometrics 101, 315-335. 
Table 1. Mean Gini coefficient by country, based on WIID.

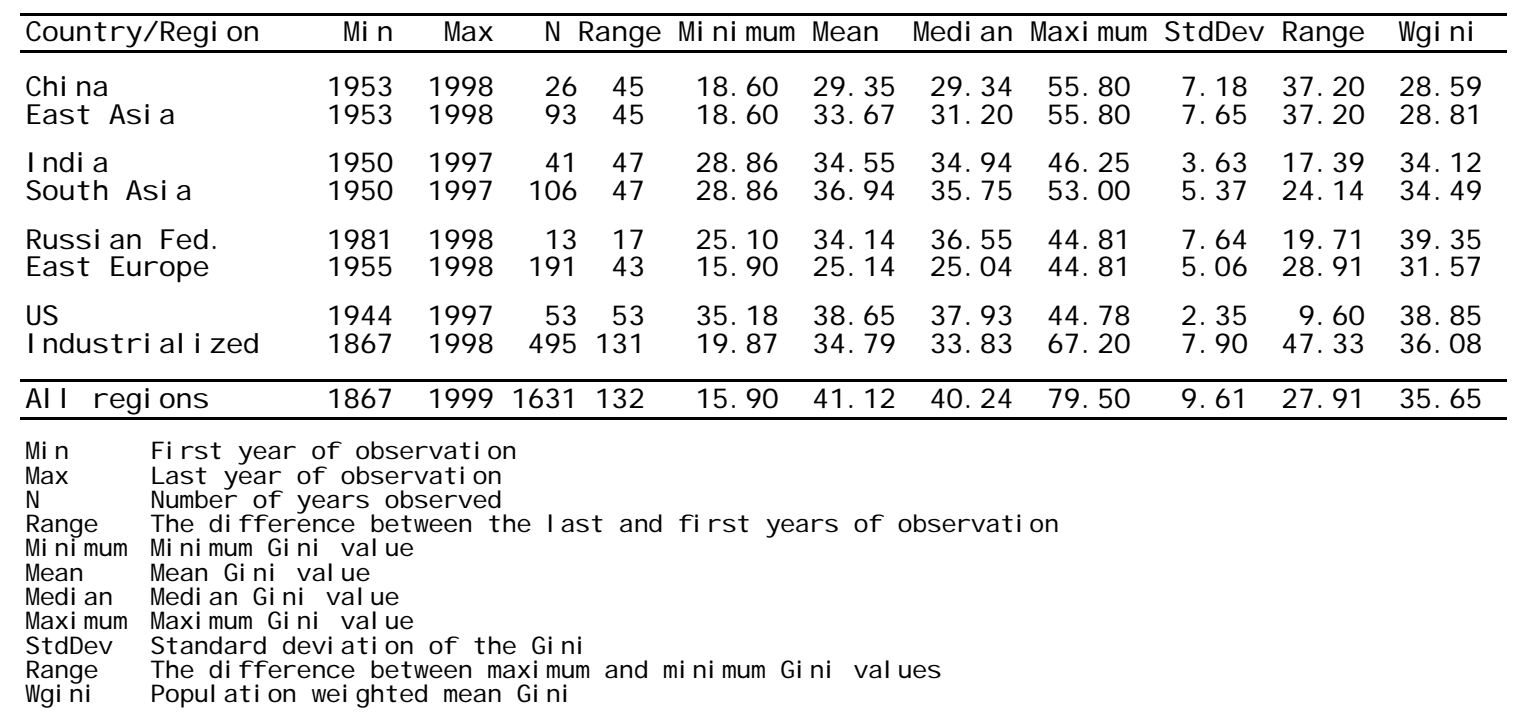


Table 2. Mean Gini coefficient and quintile shares by country, based on WIID.

\begin{tabular}{|c|c|c|c|c|c|c|c|c|c|c|c|c|}
\hline Country/Region & Mi $n$ & $\operatorname{Max}$ & $\mathrm{N}$ & Range & Gini & WGi ni & Q1 & Q2 & Q3 & Q4 & Q5 & Q5/Q1 \\
\hline $\begin{array}{l}\text { China } \\
\text { East Asia }\end{array}$ & $\begin{array}{l}1953 \\
1953\end{array}$ & $\begin{array}{l}1998 \\
1998\end{array}$ & $\begin{array}{l}26 \\
93\end{array}$ & $\begin{array}{l}45 \\
45\end{array}$ & $\begin{array}{l}29.35 \\
33.67\end{array}$ & $\begin{array}{l}28.59 \\
28.81\end{array}$ & $\begin{array}{l}0.08 \\
0.07\end{array}$ & $\begin{array}{l}0.12 \\
0.12\end{array}$ & $\begin{array}{l}0.16 \\
0.16\end{array}$ & $\begin{array}{l}0.25 \\
0.23\end{array}$ & $\begin{array}{l}0.39 \\
0.41\end{array}$ & $\begin{array}{l}5.21 \\
5.55\end{array}$ \\
\hline $\begin{array}{l}\text { India } \\
\text { South Asia }\end{array}$ & $\begin{array}{l}1950 \\
1950\end{array}$ & $\begin{array}{l}1997 \\
1997\end{array}$ & $\begin{array}{r}41 \\
106\end{array}$ & $\begin{array}{l}47 \\
47\end{array}$ & $\begin{array}{l}34.55 \\
36.94\end{array}$ & $\begin{array}{l}34.12 \\
34.49\end{array}$ & $\begin{array}{l}0.09 \\
0.08\end{array}$ & $\begin{array}{l}0.12 \\
0.12\end{array}$ & $\begin{array}{l}0.16 \\
0.16\end{array}$ & $\begin{array}{ll}0 . & 21 \\
0 . & 21\end{array}$ & $\begin{array}{l}0.41 \\
0.42\end{array}$ & $\begin{array}{l}4.83 \\
5.13\end{array}$ \\
\hline $\begin{array}{l}\text { Russian Fed. } \\
\text { East Europe }\end{array}$ & $\begin{array}{l}1981 \\
1955\end{array}$ & $\begin{array}{l}1998 \\
1998\end{array}$ & $\begin{array}{r}13 \\
191\end{array}$ & $\begin{array}{l}17 \\
43\end{array}$ & $\begin{array}{l}34.14 \\
26.14\end{array}$ & $\begin{array}{l}39.35 \\
31.57\end{array}$ & $\begin{array}{l}0.09 \\
0.10\end{array}$ & $\begin{array}{l}0.12 \\
0.14\end{array}$ & $\begin{array}{l}0.16 \\
0.18\end{array}$ & $\begin{array}{l}0.22 \\
0.22\end{array}$ & $\begin{array}{l}0.41 \\
0.35\end{array}$ & $\begin{array}{l}4.56 \\
3.54\end{array}$ \\
\hline $\begin{array}{l}\text { US } \\
\text { Industrialized }\end{array}$ & $\begin{array}{l}1944 \\
1867\end{array}$ & $\begin{array}{l}1997 \\
1998\end{array}$ & $\begin{array}{r}53 \\
495\end{array}$ & $\begin{array}{r}53 \\
131\end{array}$ & $\begin{array}{l}38.65 \\
34.79\end{array}$ & $\begin{array}{l}38.85 \\
36.08\end{array}$ & $\begin{array}{l}0.05 \\
0.07\end{array}$ & $\begin{array}{l}0.11 \\
0.12\end{array}$ & $\begin{array}{l}0.17 \\
0.17\end{array}$ & $\begin{array}{l}0.24 \\
0.24\end{array}$ & $\begin{array}{l}0.43 \\
0.40\end{array}$ & $\begin{array}{l}9.17 \\
5.72\end{array}$ \\
\hline All regions & 1867 & 1999 & 1392 & 2132 & 38.06 & 38.26 & 0.07 & 0.11 & 0.16 & 0.22 & 0.44 & 6.88 \\
\hline $\begin{array}{l}\text { First yea } \\
\text { Last year } \\
\text { Number of } \\
\text { The diffe } \\
\text { Mean Gi ni } \\
\text { Popul at io } \\
\text { Income sh } \\
\text { the ratio }\end{array}$ & $\begin{array}{l}\text { ar of obs } \\
\text { of obse } \\
\text { years } 0 \\
\text { erence be } \\
\text { value } \\
\text { on weight } \\
\text { hare of } t \\
\text { on of the }\end{array}$ & $\begin{array}{l}\text { ervatio } \\
\text { rvation } \\
\text { bserved } \\
\text { tween t } \\
\text { ed mean } \\
\text { he firs } \\
\text { fifth }\end{array}$ & $\begin{array}{l}\text { on } \\
\text { n } \\
\text { d } \\
\text { the I a } \\
\text { n Gini } \\
\text { st-fift } \\
\text { quint }\end{array}$ & $\begin{array}{l}\text { ast and } \\
\text { i val ue } \\
\text { fth quin } \\
\text { tile sha }\end{array}$ & $\begin{array}{l}\text { ntiles } \\
\text { are to }\end{array}$ & $\begin{array}{l}\text { f popul } \\
\text { he fir }\end{array}$ & $\begin{array}{l}\text { tion } \\
\text { quin }\end{array}$ & tion & & & & \\
\hline
\end{tabular}


Table 3. Development of Gini coefficient and quintile income shares by country.

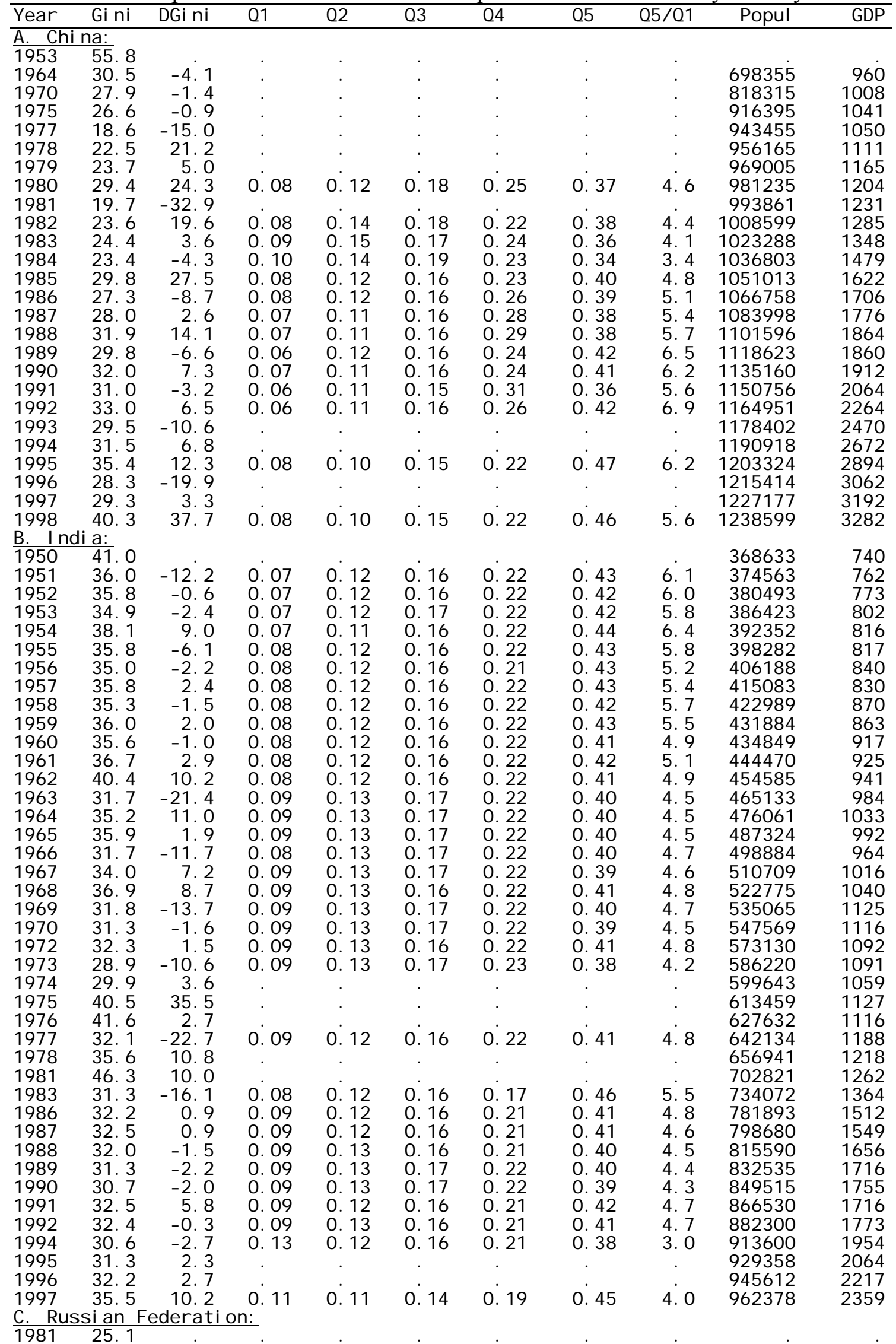




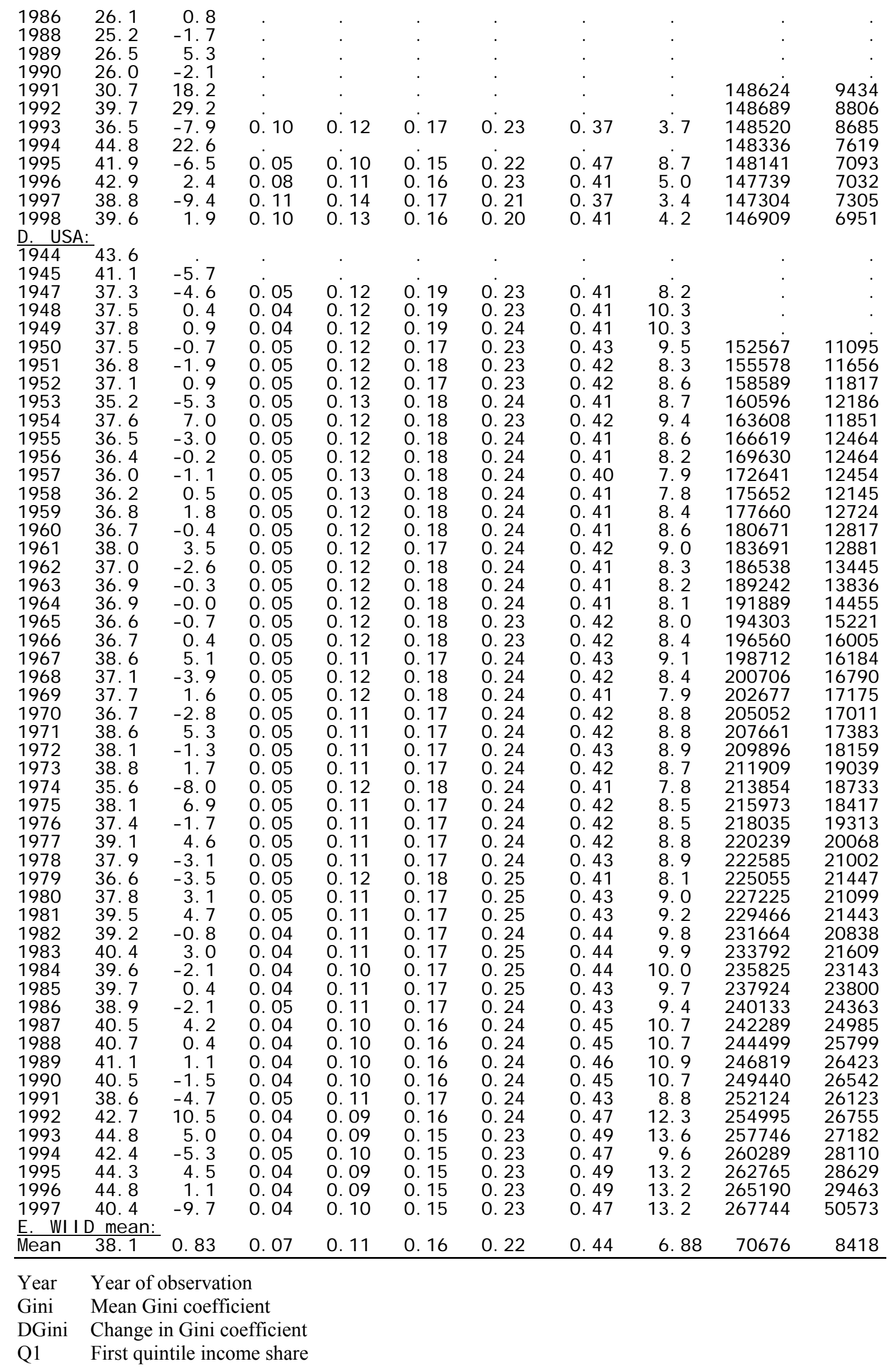


Q2 Second quintile income share

Q3 Third quintile income share

Q4 Fourth quintile income share

Q5 Fifth quintile income share

Q5/Q1 Ratio of the fifth to the first quintile income shares

Popul Population in 1000

GDP Read GDP per capita 
Figure 1. Development of Gini and income shares in China.

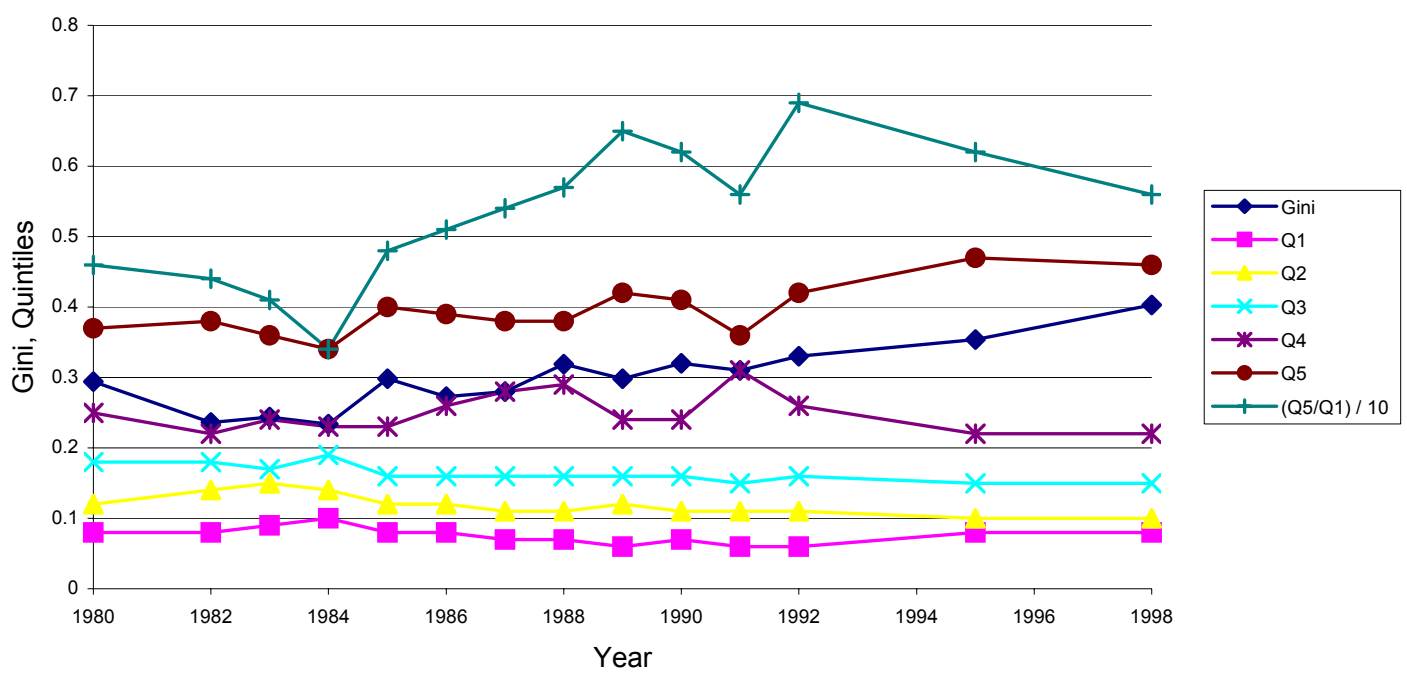

Figure 2. Development of Gini and income shares in India.

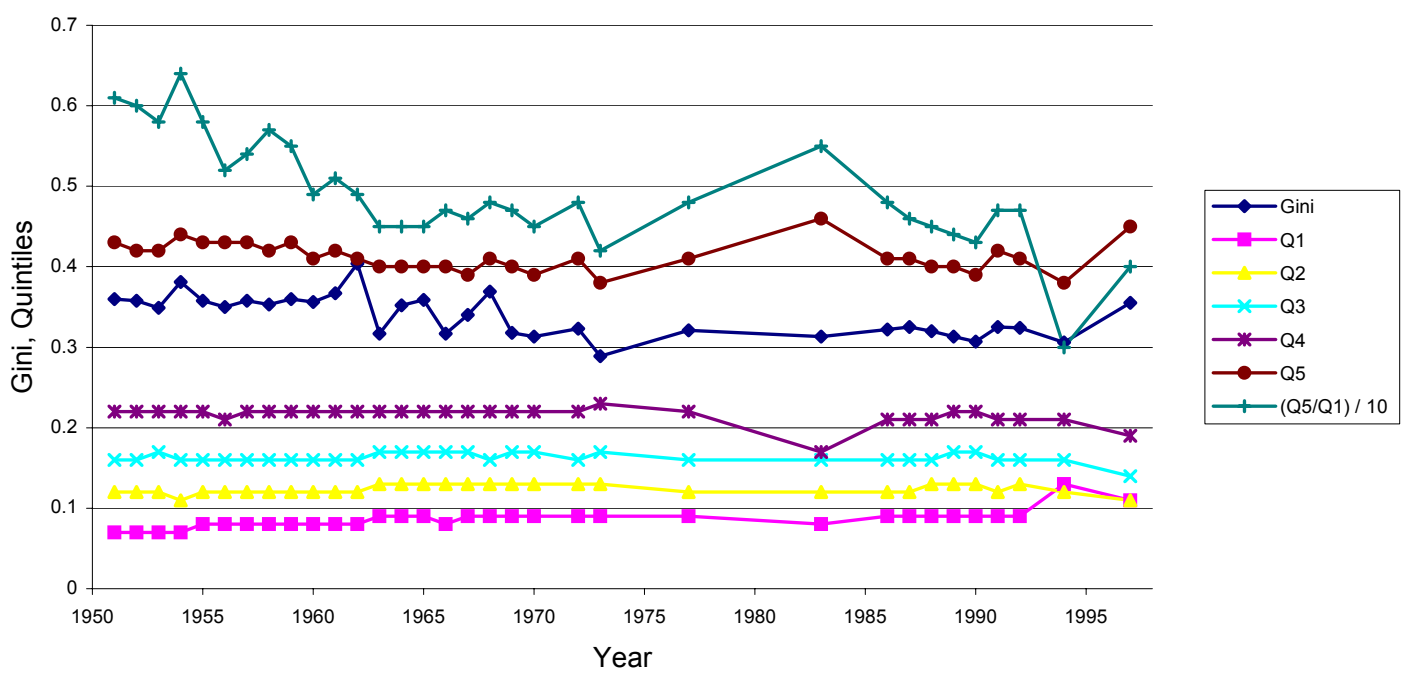


Figure 3. Development of Gini and income shares in Russian Federation.

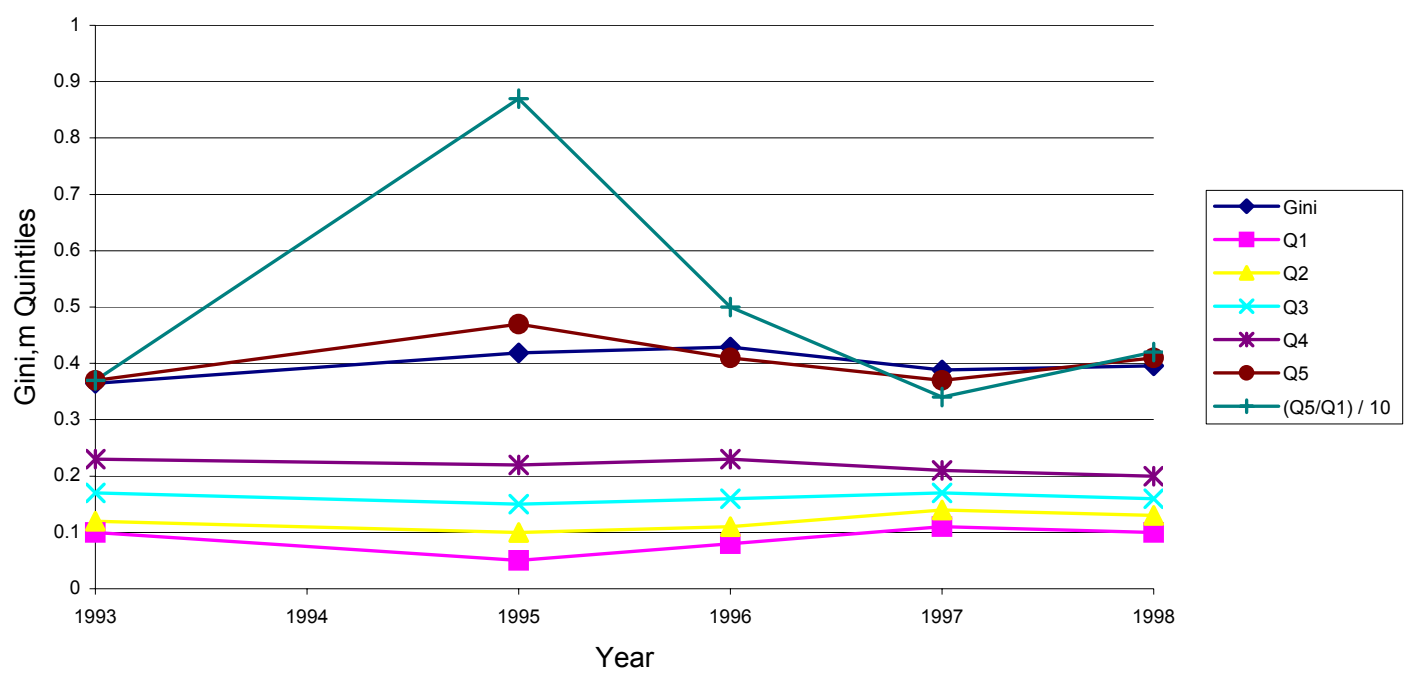

Figure 4. Development of Gini and income shares in USA.

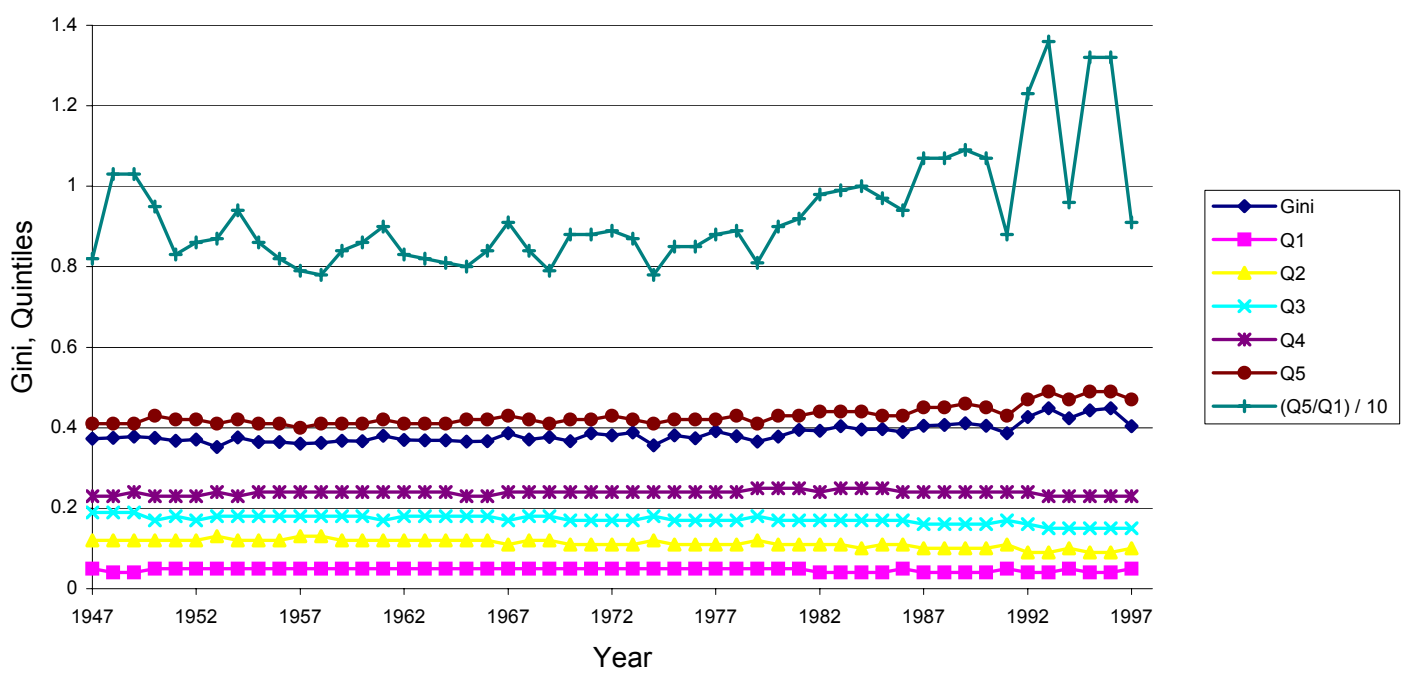


Figure 5. Development of Gini coefficient by country.

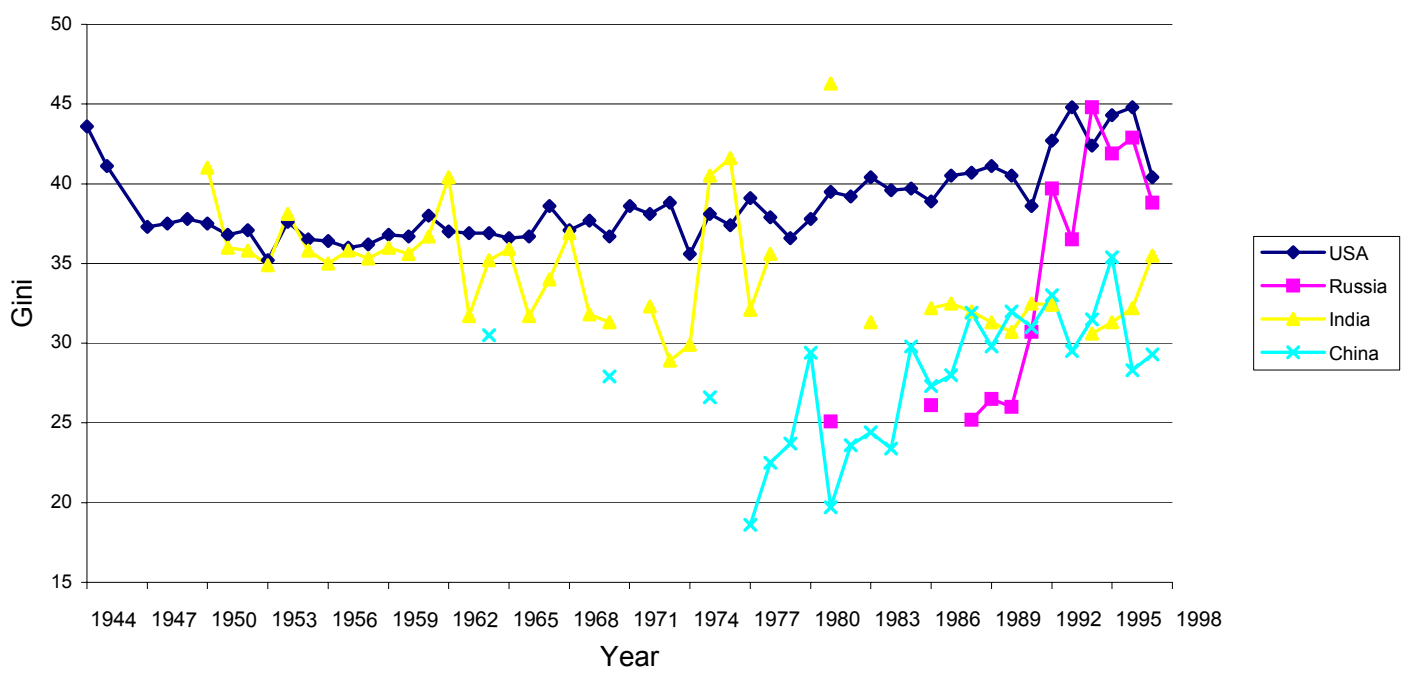

